OPEN ACCESS

Edited by:

Vasile I. Parvulescu, University of Bucharest, Romania

Reviewed by: Inamuddin, Aligarh Muslim University, India Bin Mu, Lanzhou Institute of Chemical Physics (CAS), China

*Correspondence: Fan Zhang chemfzhang@163.com

Specialty section:

This article was submitted to Green and Sustainable Chemistry, a section of the journal Frontiers in Chemistry

Received: 14 November 2021 Accepted: 17 January 2022

Published: 04 March 2022

Citation:

Wang $Q$, Zhu S, Xi C and Zhang F (2022) A Review: Adsorption and Removal of Heavy Metals Based on

Polyamide-amines Composites.

Front. Chem. 10:814643.

doi: 10.3389/fchem.2022.814643

\section{A Review: Adsorption and Removal of Heavy Metals Based on Polyamide-amines Composites}

\author{
Qian Wang, Sining Zhu, Chen Xi and Fan Zhang* \\ Key Laboratory of Mineral Cleaner Production and Exploit of Green Functional Materials in Hunan Province, College of Chemistry \\ and Chemical Engineering, Jishou University, Jishou, China
}

In recent years, the problem of heavy metal pollution has become increasingly prominent, so it is urgent to develop new heavy metal adsorption materials. Compared with many adsorbents, the polyamide-amine dendrimers (PAMAMs) have attracted extensive attention of researchers due to its advantages of macro-molecular cavity, abundant surface functional groups, non-toxicity, high efficiency and easy modification. But in fact, it is not very suitable as an adsorbent because of its solubility and difficulty in separation, which also limits its application in environmental remediation. Therefore, in order to make up for the shortcomings of this material to a certain extent, the synthesis and development of polymer composite materials based on PAMAMs are increasingly prominent in the direction of solving heavy metal pollution. In this paper, the application of composites based on PAMAMs and inorganic or organic components in the adsorption of heavy metal ions is reviewed. Finally, the prospects and challenges of PAMAMs composites for removal of heavy metal ions in water environment are discussed.

Keywords: polyamide-amines, composites, adsorption, heavy metals, waste water

\section{INTRODUCTION}

With the rapid development of electroplating, metallurgy, mining, textile leather industry and urbanization, a large number of heavy metal ions such as $\mathrm{Pb}^{2+} \mathrm{As}^{2+}, \mathrm{Cd}^{2+}, \mathrm{Cr}^{2+}$, and $\mathrm{Hg}^{2+}$ are being discharged into the aquatic environment via natural environment and man-made means, which contain not only toxic heavy metal ions, but also radioactive elements (Ma et al., 2017a; Luo et al., 2017; Ling et al., 2020; Surgutskaia et al., 2020). The heavy metal pollutants are different from organic pollutants and can't be biodegraded, the heavy metal ions present in wastewater pose a threat to the environment and human health if not properly being treated. Therefore, the management of heavy metal ions in the environment and the reduction of their content to the allowable concentration are very noteworthy. At present, the main treatment methods for wastewater containing heavy metal ions include the ferrite method, chemical precipitation, the electrochemical method, the reverse osmosis method, the ion exchange method, the adsorption method, and so on (Zhang et al., 2016a; Chen et al., 2021; Mariana et al., 2021). Among them, both ion-exchange and electrochemical methods have high sensitivity and selectivity, but there are shortcomings such as time-consuming, expensive, limited equipment and so on. The adsorption method (Shih et al., 2019; Yuan et al., 2021) has the advantages of large adsorption capacity, fast adsorption speed, recycleability, simple operation, but the preparation process of some heavy metal adsorption materials is complex and the cost is expensive. It can be seen that the existing heavy metal treatment technologies have some deficiencies in one or more aspects (Li et al., 2021). Therefore, it is desirable to consider a method 


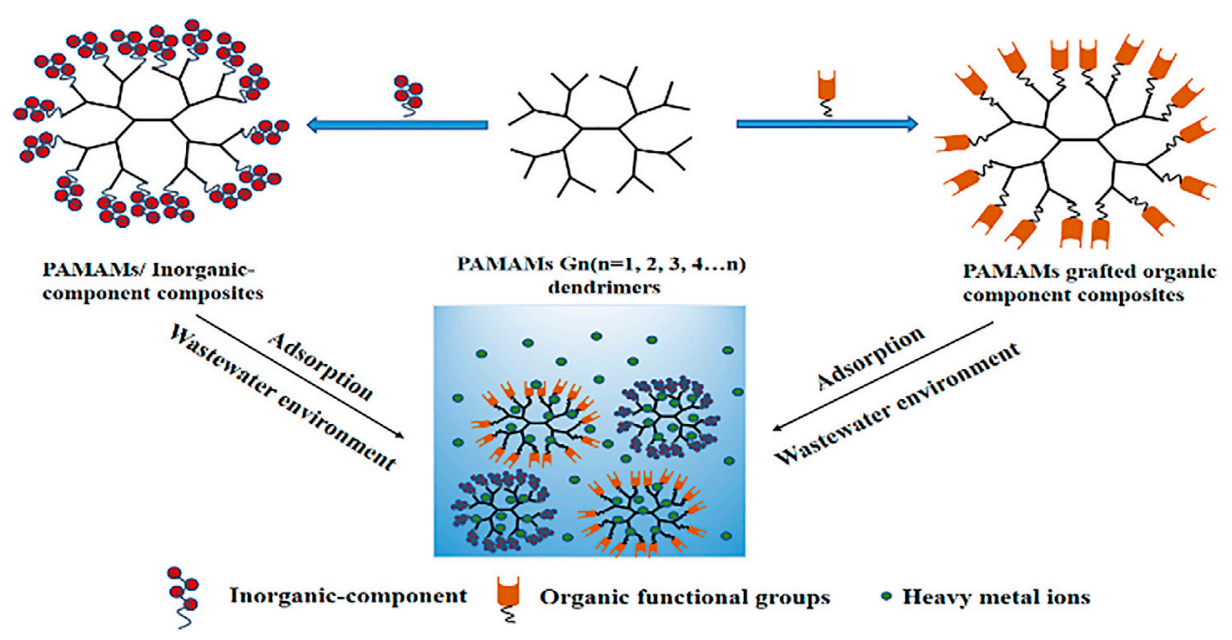

GRAPHICAL ABSTRACT |

with maximum removal efficiency for heavy metal ions. In previous studies, different kinds of functional groups have been used to construct novel adsorbents (Weidman et al., 2017). Dendritic polymers have attracted great interest in environmental remediation, nanoparticle synthesis, and nanomedicine applications due to their excellent chelating properties (Astruc and Chardac, 2001; Myers et al., 2011). Among them, the most widely studied is the low-toxic polyamide-amine dendrimers (PAMAMs) (Lard et al., 2010). It was first reported in the 1980s and was also the first type of commercial dendritic polymer. Applications of PAMAMs were initially focused on generations with flat ellipsoid shapes (Liu et al., 2005). However, the higher generation of dendritic macromolecules (4 and up) are starburst shaped and logically extended, making them particularly attractive for modern applications (Valdés et al., 2016). At present, there are two main diverse synthesis strategies to synthesize dendritic polyamide-amine with clear structure, namely the convergent growth and divergent growth methods (Hawker and Frechet, 1990; Tomalia, 2005; Tomalia et al., 2010), both of which need to accurately control the growth of its spatial molecular weight. Meanwhile, a divergent convergence method and solid-phase synthesis technologies are both in continuous development (Swali et al., 1997). Some studies have shown that heavy metal ions have a strong affinity with compounds containing amino groups (Aguado et al., 2009; Vasiliev et al., 2009). Since PAMAMs have a large number of terminal amino groups and high specific surface areas, they are considered to be the best choice for forming complexes with metal ions, which makes them be more and more used in the environment. However, the chelate formed by PAMAMs and metal ions has good solubility, which limits its application for the treatment of heavy metal ions (Song et al., 2017). PAMAMs and their modified composites have shown excellent performance in adsorbing environmental pollutants such as heavy metal ions, along with organic and composite pollutions adsorption. Therefore, PAMAMs are used as the main functional groups to prepare the composites with both inorganic and organic components. On the basis of ensuring the structure of the original adsorbent, improving the chelating capacity of heavy metal ions, and achieving the easy separation and recovery after adsorption, which has become an important technical direction in the design of the material for the removal of heavy metal ions.

In this paper, the preparation of the composites based on PAMAMs and inorganic functional components or organic functional groups and their application to the adsorption of heavy metals are reviewed in detail. Finally, future perspectives and challenges encountered with polyamide amines are stated and elaborated, and recommendations are provided for further study.

\section{THE PAMAMS/INORGANIC-COMPONENT COMPOSITES AND THEIR ADSORPTION FOR HEAVY METALS}

\section{PAMAMs/Carbon-Based Composites PAMAMs/Graphene Oxide Composites}

Graphene oxide (GO) is a kind of graphene-based material. Recently, GO has shown strong adsorption capacity due to its large specific surface area and rich oxygen-containing functional groups, including carboxyl, ketone, epoxy, and hydroxyl, which provides various active sites for the modification and adsorption of target pollutants (Zhang et al., 2011; Zhao et al., 2011). However, $\mathrm{GO}$ is difficult to separate from aqueous solutions because of its easy dispersion in water, which is likely to cause secondary pollution. Therefore, $\mathrm{GO}$ is further functionalized for the purpose of improving its surface properties, so as to facilitate separation and improve adsorption efficiency. Several strategies have been applied to address these extant problems, such as the modification of GO with polymers containing $\mathrm{N}, \mathrm{S}$ and $\mathrm{O}$ functional groups to improve the type and number of functional groups on the GO surface, thereby increasing the ability of GO for removing heavy metal ions (Kong et al., 2021). Table 1 presented some research cases about the 
TABLE 1 | Heavy metal ions adsorbed by polyamide amine/graphene oxide composites.

\begin{tabular}{|c|c|c|c|c|c|}
\hline Adsorbents & Metal ions & $Q_{\mathrm{e}}(\mathrm{mg} / \mathrm{g})$ & Conditions & Model (adsorption isotherm; kinetics) & References \\
\hline GO-PAMAM-COO- & $\mathrm{Pb}^{2+}$ & 1523.1 & $298 \mathrm{~K} ; \mathrm{pH} 7.0 ; \mathrm{C}_{0}=0.5 \mathrm{~mol} / \mathrm{L}$ & Langmuir isotherm model & Kommu et al. (2017) \\
\hline \multirow[t]{3}{*}{ HMGO-PAMAM-G1.0 } & $\mathrm{Pb}^{2+}$ & 108.06 & $298 \mathrm{~K} ; \mathrm{pH} 6.2 ; \mathrm{C}_{0}=300 \mathrm{mg} / \mathrm{L}$ & Langmuir isotherm model & Ma et al. (2018) \\
\hline & $\mathrm{Hg}^{2+}$ & 288.68 & $298 \mathrm{~K} ; \mathrm{pH} 6.2 ; \mathrm{C}_{0}=300$ mg/L & Pseudo-second-order & \\
\hline & $\mathrm{Pb}^{2+}$ & 568.18 & $298 \mathrm{~K} ; \mathrm{pH} 4.5 ; \mathrm{C}_{0}=6 \mathrm{mmol} / \mathrm{L}$ & & \\
\hline \multirow[t]{3}{*}{ GO/PAMAMs } & $\mathrm{Cd}^{2+}$ & 253.81 & $298 \mathrm{~K} ; \mathrm{pH} 5.0 ; \mathrm{C}_{0}=6 \mathrm{mmol} / \mathrm{L}$ & Langmuir isotherm model & Lotfi et al. (2019) \\
\hline & $\mathrm{Cu}^{2+}$ & 68.68 & $298 \mathrm{~K} ; \mathrm{pH} 4.5 ; \mathrm{C}_{0}=6 \mathrm{mmol} / \mathrm{L}$ & Pseudo-second-order & \\
\hline & $\mathrm{Mn}^{2+}$ & 18.29 & $298 \mathrm{~K} ; \mathrm{pH} 4.0 ; \mathrm{C}_{0}=6 \mathrm{mmol} / \mathrm{L}$ & & \\
\hline MGO-PAMAM & $\mathrm{Hg}^{2+}$ & 113.71 & $298 \mathrm{~K} ; \mathrm{pH} 6.0 ; \mathrm{C}_{0}=100 \mathrm{mg} / \mathrm{L}$ & $\begin{array}{l}\text { Langmuir isotherm model } \\
\text { Pseudo-second-order }\end{array}$ & Ma et al. (2017b) \\
\hline GO-PAMAMs & $\mathrm{Cr}^{6+}$ & 211.42 & $313 \mathrm{~K} ; \mathrm{pH} 2.5 ; \mathrm{C}_{0}=240 \mathrm{mg} / \mathrm{L}$ & $\begin{array}{l}\text { Langmuir isotherm model } \\
\text { Pseudo-second-order }\end{array}$ & Liu et al. (2019) \\
\hline \multirow[t]{3}{*}{ mGO2nd-PAMAM nanosheets } & $\mathrm{Cd}^{2+}$ & 435.85 & $298 \mathrm{~K} ; \mathrm{pH} 7.0 ; \mathrm{C}_{0}=30 \mathrm{mg} / \mathrm{L}$ & Freundlich isotherm model & Einollahi Peer et al. (2018) \\
\hline & $\mathrm{Pb}^{2+}$ & 326.729 & $298 \mathrm{~K} ; \mathrm{pH} 6.0 ; \mathrm{C}_{0}=20 \mathrm{mg} / \mathrm{L}$ & $\mathrm{R}-\mathrm{P}$ isotherm model & \\
\hline & $\mathrm{Cu}^{2+}$ & 353.59 & $298 \mathrm{~K} ; \mathrm{pH} 7.0 ; \mathrm{C}_{0}=20 \mathrm{mg} / \mathrm{L}$ & Langmuir isotherm model & \\
\hline
\end{tabular}

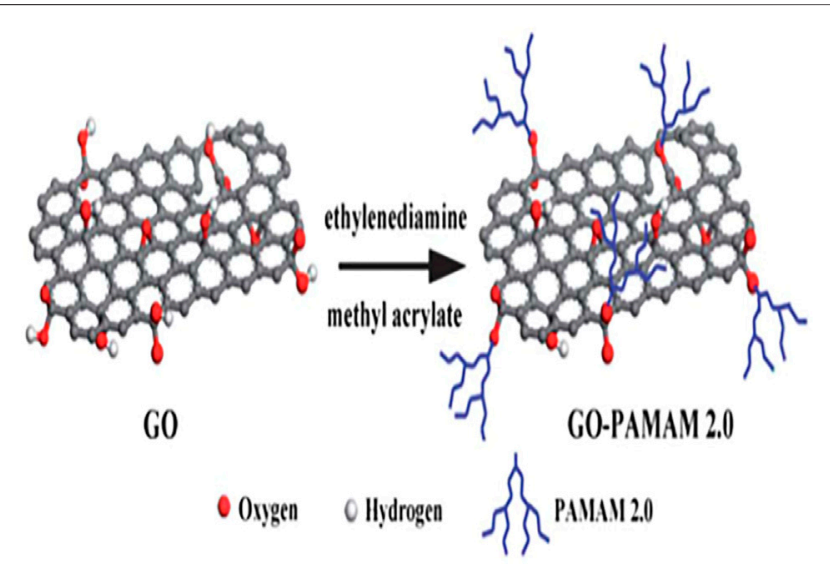

FIGURE 1 | Illustration of the preparation of GO-PAMAM 2.0.

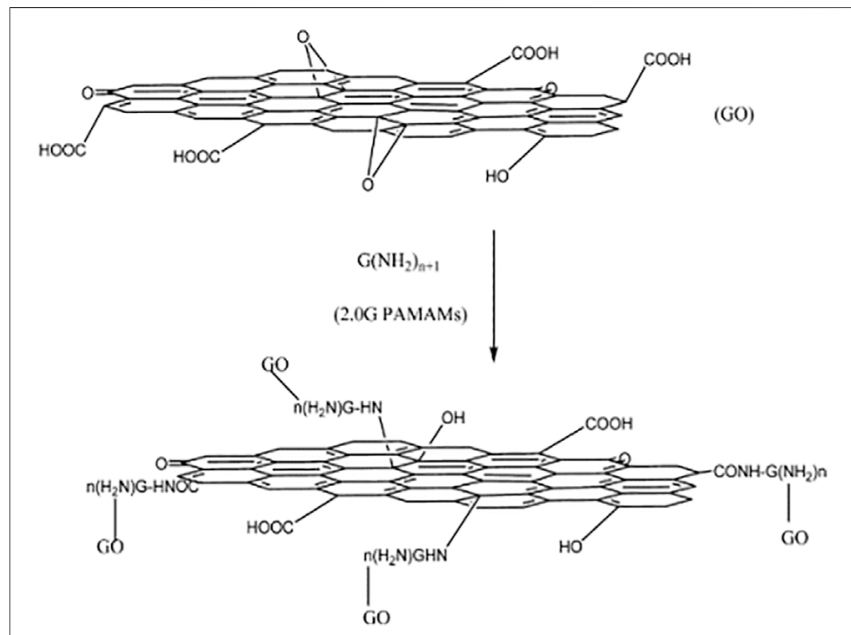

FIGURE 2 | Preparation of GO/PAMAMs composites.

PAMAMs/GO composites and their adsorbtion of heavy metals $\left(\mathrm{Pb}^{2+}, \mathrm{Cu}^{2+}, \mathrm{Hg}^{2+}, \mathrm{Mn}^{2+}, \mathrm{Cd}^{2+}, \mathrm{Cr}(\mathrm{VI})\right.$, etc. $)$. Obviously, compounding with PAMAMs is a good strategy. For example,
Xiao et al. (2016) prepared different generations of PAMAMs functionalized GO (GO-PAMAM) to adsorb Se (IV) and Se (VI) from aqueous solution, Lotfi et al. (2019) designed a new synthesis strategy to investigate dithiocarbamate (DTC) grafted magnetic GO (DTC-D-MGO), the DTC-D-MGO was used as adsorbent for extraction of heavy metals in food and water samples. The GO was modified with PAMAMs via a grafting-from method (as shown in Figure 1.) (Yuan et al., 2013). The magnetic GO composites (mGO) were grafted with the first and second generation of polyamidoamine dendrimers and showed their superior adsorption performance for heavy metal ions (Einollahi Peer et al., 2018). Ma (Ma et al., 2017b; Ma et al., 2018) prepared a low generation hexamethylenediamine type polyamide-amine dendritic macromolecule (HMGO-PAMAM-G1.0) with longer hydrophobic chain length by Michael addition and amidation condensation reaction, which exhibited a higher adsorption capacity for $\mathrm{Pb}(\mathrm{II})$ and $\mathrm{Hg}(\mathrm{II})$ heavy metal ions at higher concentrations. Kommu et al. (2017) applied molecular dynamics simulation to explore the effect of PAMAMs grafted $\mathrm{GO}$ on the dynamical and structural properties of $\mathrm{Pb}$ (II) ions.

Zhang et al. (2014) prepared graphene oxide/polyamideamine dendrimers (GO-PAMAMs) by "grafting method" (as shown in Figure 2), the research showed that the adsorption capacity of GO-PAMAMs for heavy metal ions was highly correlated with $\mathrm{pH}$ and its maximum adsorption capacity for $\mathrm{Pb}$ (II) was $568.18 \mathrm{mg} / \mathrm{g}$ (Liu et al., 2019).

\section{PAMAMs/Carbon nanotubes(CNTs) Composites}

In 1991, Ilijima (1991) discovered carbon nanotubes (CNTs) in the cathode deposits of fullerene production by high-resolution microscopy (HRTEM). CNTs are nano-scale hollow tubes made of graphite sheets coiled according to a certain helicity, with a high specific surface area. However, the coagulated suspension of carbon nanotubes in an aqueous solution is caused by the strong intermolecular force between carbon nanotubes, which has a considerable impact on the adsorption performance (Tofighy and Mohammadi, 2011; Ihsanullah et al., 2015; Xie et al., 2015). To improve the suspension concentration of free nanotubes and the adsorption performance of the CNTs, the modification of their surface is the most useful method, which 


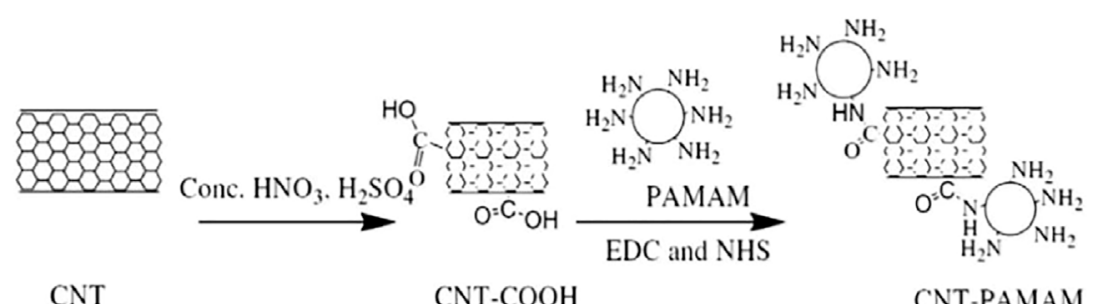

FIGURE 3 | Synthesis process of PAMAM/CNT nanocomposites.

TABLE 2 | Heavy metal ions adsorbed by polyamide amine/magnetic nanomaterial composites.

\begin{tabular}{|c|c|c|c|c|c|}
\hline Adsorbents & $\begin{array}{l}\text { Metal } \\
\text { ions }\end{array}$ & $\begin{array}{c}Q_{e} \\
(\mathrm{mg} / \mathrm{g})\end{array}$ & Conditions & $\begin{array}{c}\text { Model (adsorption isotherm; } \\
\text { kinetics) }\end{array}$ & References \\
\hline $\mathrm{Fe}_{3} \mathrm{O}_{4} @ \mathrm{SiO}_{2}-\mathrm{M} 2$ & $\begin{array}{c}\mathrm{Hg}^{2+} \\
\mathrm{Ag}^{+}\end{array}$ & $\begin{array}{l}160.47 \\
139.15\end{array}$ & $\begin{array}{l}308.15 \mathrm{~K} ; \mathrm{pH} 6.0 ; \mathrm{C}_{0}=0.005 \mathrm{~mol} / \mathrm{L} \\
308.15 \mathrm{~K} ; \mathrm{pH} 6.0 ; \mathrm{C}_{0}=0.005 \mathrm{~mol} / \mathrm{L}\end{array}$ & $\begin{array}{l}\text { Langmuir isotherm model } \\
\text { Pseudo-second-order }\end{array}$ & Luan et al. (2021a) \\
\hline MNPs-G2-Mu & $\mathrm{Pb}^{2+}$ & 232.56 & $298 \mathrm{~K} ; \mathrm{pH} 5.0 ; \mathrm{C}_{0}=200 \mathrm{mg} / \mathrm{L}$ & $\begin{array}{l}\text { Langmuir isotherm model } \\
\text { Pseudo-second-order }\end{array}$ & Ekinci et al. (2021) \\
\hline $\mathrm{Fe}_{3} \mathrm{O}_{4} @ \mathrm{PDA} @ \mathrm{PAMAM}$ & $\mathrm{Cu}^{2+}$ & 97.18 & $298 \mathrm{~K} ; \mathrm{pH} 7.0 ; \mathrm{C}_{0}=80 \mathrm{mg} / \mathrm{L}$ & $\begin{array}{l}\text { Langmuir isotherm model } \\
\text { Pseudo-second-order }\end{array}$ & Sun et al. (2018) \\
\hline $\mathrm{Fe}_{3} \mathrm{O}_{4} @ \mathrm{DA} @ \mathrm{PAMAM}$ & $\begin{array}{l}\mathrm{Cu}^{2+} \\
\mathrm{Pb}^{2+} \\
\mathrm{Cd}^{2+}\end{array}$ & $\begin{array}{l}209.7 \\
262.1 \\
150.2\end{array}$ & $298 \mathrm{~K} ; \mathrm{pH} 7.0 ; \mathrm{C}_{0}=80 \mathrm{mg} / \mathrm{L}$ & - & Wang et al. (2020) \\
\hline CT-HPMNPS & $\mathrm{Hg}^{2+}$ & 72.3 & $298 \mathrm{~K} ; \mathrm{pH} 5.0 ; \mathrm{C}_{0}=20$ mg/L & $\begin{array}{l}\text { Freundlich isotherm model } \\
\text { Pseudo-second-order }\end{array}$ & $\begin{array}{l}\text { Tabatabaiee Bafrooee et al. } \\
(2020)\end{array}$ \\
\hline PAMAMG3- $\mathrm{Fe}_{3} \mathrm{O}_{4} / \mathrm{P}$ (GMA-AA-MMA) & $U^{6+}$ & 395.2 & $298 \mathrm{~K} ; \mathrm{pH} 4.5 ; \mathrm{C}_{0}=150 \mathrm{mg} / \mathrm{L}$ & $\begin{array}{l}\text { Langmuir isotherm model } \\
\text { Pseudo-second-order }\end{array}$ & Yuan et al. (2016) \\
\hline PAMAM-MNC & $\mathrm{Pb}^{2+}$ & 333 & $298 \mathrm{~K} ; \mathrm{pH} 5-6 ; \mathrm{C}_{0}=1,000 \mathrm{mg} / \mathrm{L}$ & $\begin{array}{l}\text { Langmuir isotherm model } \\
\text { Pseudo-second-order }\end{array}$ & Pourjavadi et al. (2016) \\
\hline $\mathrm{Fe}_{3} \mathrm{O}_{4} @ \mathrm{SiO}_{2}-\mathrm{G} 2.0-\mathrm{S}$ & $\mathrm{Hg}^{2+}$ & 605.78 & $308 \mathrm{~K} ; \mathrm{pH} 6.0 ; \mathrm{C}_{0}=0.01 \mathrm{~mol} / \mathrm{L}$ & $\begin{array}{l}\text { Langmuir isotherm model } \\
\text { Pseudo-second-order }\end{array}$ & Zhou et al. (2020) \\
\hline
\end{tabular}

not only enhances the dispersion behavior but also provides more binding sites for the adsorption of metal ions and organic pollutants (Gupta et al., 2016; Hadavifar et al., 2014). For example,Baghayeri et al. (2021) has synthesized PAMAMs covalently functionalized magnetic multi-walled carbon nanotubes for the determination of trace As(III) in an aqueous matrix. The CNTs-coated polyamine dendrimers (PAMAMs) were prepared and used as adsorbents (the composite diagram shown from Figure 3) (Hayati et al., 2017; Hayati et al., 2018), and the results exhibited that PAMAMs-CNT could be effectively used as a novel super absorbent for heavy metal adsorption in multicomponent systems.

\section{PAMAMs/Biochar Composites}

In recent years, biochar has attracted more and more attention for its unique advantages of a simple synthesis process, low cost, high cation exchange ability, and low environmental impact (Zhao et al., 2017). However, due to the low specific surface area and the limited number of surface functional groups of original biochar, its adsorption and removal efficiency are limited. Thus, original biochar is validly modified to improve the removal performance of contaminants in water by using functional groups that can provide affluent active sites and electrostatic action (Tan et al., 2016; Zhang et al., 2019a; Feng et al., 2020). Yin et al. (2021) prepared a novel magnetic biochar modified with PAMAMs for $\mathrm{Cu}(\mathrm{II})$ adsorption, the results indicated that it was an efficient $\mathrm{Cu}(\mathrm{II})$ adsorbent and its good recycling performance could also provide a renewable method for resource utilization.

\section{PAMAMs/Magnetic Nanomaterial Composites}

Great breakthroughs have been made in the development of water treatment technology, and the development and application of adsorption methods are more and more frequent. However, there are deficiencies apparent in the recovery, separation, and reuse of heavy metal adsorbents. The magnetic nanomaterial makes up for these deficiencies to a certain extent owing to the easy phase separation after treatment (Moazzen et al., 2019; Venkateswarlu et al., 2015; Wei et al., 2012). Among many nano-magnetic materials, magnetic $\mathrm{Fe}_{3} \mathrm{O}_{4}$ is the most common and widely used, which can achieve magnetic separation in a short time under the action of an external magnetic field (Zhang et al., 2013). However, bare $\mathrm{Fe}_{3} \mathrm{O}_{4}$ nanoparticles show poor adsorption 

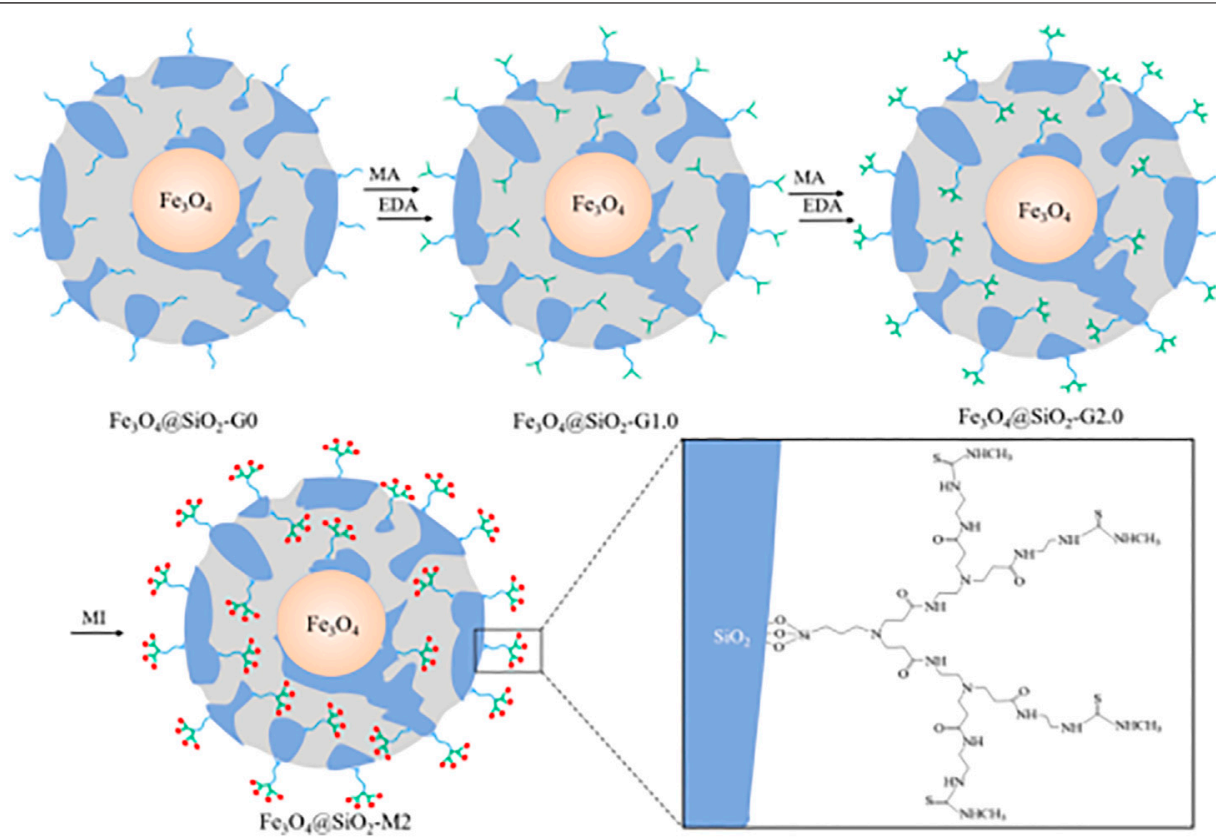

FIGURE 4 | The synthetic procedures for $\mathrm{Fe}_{3} \mathrm{O}_{4} @ \mathrm{SiO}_{2}-\mathrm{M} 2$.

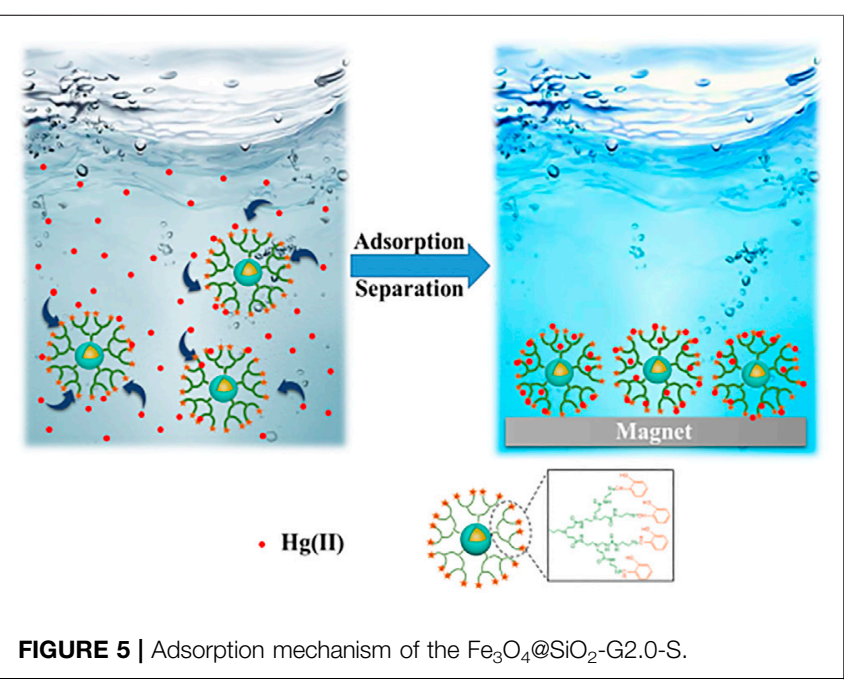

performance and chemical stability, which limits their application in the remediation of heavy metal ion contamination. Some research published had reported that the modification of the surface of magnetic nanoparticles played a significant role to improve their stability and adsorption properties. Synthesis of organic-inorganic nano-composites is a common method to modify the surface of magnetic nanoparticle (Wang et al., 2010; Liang et al., 2017; Kido et al., 2012). The heavy metals $\left(\mathrm{Pb}^{2+}, \mathrm{Cu}^{2+}, \mathrm{Hg}^{2+}, \mathrm{Ag}^{+}, \mathrm{Cd}^{2+}\right.$, etc. $)$ adsorbed by PAMAMs/ magnetic nanomaterials are summarized in Table 2, the PAMAMs/magnetic composites presented good adsorption properties. For example, Luan et al. (2021a) immobilized sulfur functionalized PAMAMs on magnetic $\mathrm{Fe}_{3} \mathrm{O}_{4}$ composites
$\left(\mathrm{Fe}_{3} \mathrm{O}_{4} @ \mathrm{SiO}_{2}-\mathrm{M} 2\right)$ (as shown in Figure 4) by combining the advantages of the two components, $\mathrm{Ag}$ (I) and $\mathrm{Hg}$ (II) can be efficiently and selectively captured and its removal rate of $\mathrm{Hg}^{2+}$ was always more than $93.22 \%$ after four adsorption-desorption cycles. Sun et al. (2018) successfully prepared core-shell nanocomposites $\left(\mathrm{Fe}_{3} \mathrm{O}_{4} @ \mathrm{PDA} @ \mathrm{PAMAM}\right)$ by synthesis of monodisperse $\mathrm{Fe}_{3} \mathrm{O}_{4}$ nanoflower, which had a high adsorption capacity for $\mathrm{Cu}$ (II). Wang et al. (2020) prepared macroporous adsorption resin by sol-gel phase separation and grafted it with dopamine (DA) and polyamide-amines (PAMAMs) for heavy metal ion adsorption. The PAMAMs dendrimer/magnetic $\mathrm{Fe}_{3} \mathrm{O}_{4}$ composites were prepared by Zhou et al. (2020), and the adsorption mechanism was shown in Figure 5. The research work not only explored an improved preparation strategy of a synthetic adsorbent based on functionalized PAMAMs dendritic macromolecules, but also provided an adsorbent with potential application prospects for effective removal of $\mathrm{Hg}$ (II) from aqueous solution.

Obviously, there are still some deficiencies, such as previous researches were found that $\mathrm{Fe}_{3} \mathrm{O}_{4}$ was easy to be oxidized or corroded, which weakened its magnetism. In addition, iron oxide had poor solubility and tended to form iron hydroxide precipitation at low $\mathrm{pH}$ value, and it was not easy to form iron oxide gel.

Pourjavadi et al. (2016) polymerized methyl acrylate on the surface of activated magnetic particles and then grafted PAMAMs with methyl acrylate group to prepare magnetic nanocomposites (PAMAM-MNC). In general, the composite adsorbent obtained by modifying magnetic nano-material with PAMAMs has a certain potential application value for the development of heavy metal adsorption research. Ekinci et al. (2021) successfully prepared magnetically separable nanoadsorbents 


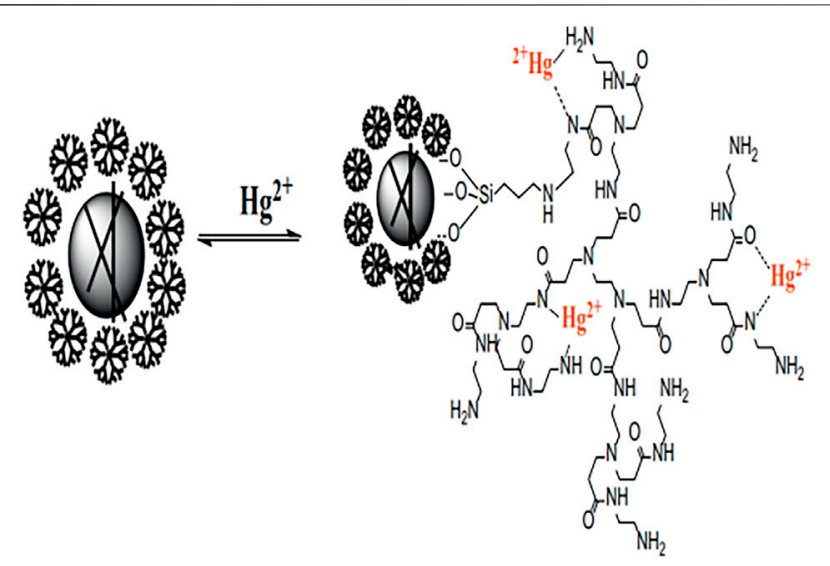

FIGURE 6 | Proposed binding mechanism of PAMAM-ATP with $\mathrm{Hg}(\mathrm{II})$.

(MNPs-G2-Mu) by covalently grafting polyamide-amine dendrimers onto magnetite nanoparticles coated with 3aminopropyl functionalized silica, and applied them to the efficient removal of $\mathrm{Pb}$ (II) in aqueous solution. Compared with other traditional methods, the magnetic separation technology of the MNPs-G2-Mu nano-adsorbent is a relatively simple, economical, and efficient method. Bafrooee (Tabatabaiee Bafrooee et al., 2020) synthesized carboxyl terminated hyperbranched polyamide dendrimer grafted with core-shell superparamagnetic nanoparticles (CT-HPMNPs) by chemical coprecipitation method, which was used as a new adsorbent to remove $\mathrm{Hg}$ (II) from water. The results show that CT-HPMNPs have significant removal potential for $\mathrm{Hg}$ (II) ions in industrial wastewater and labeled water. Even after 10 regeneration cycles, the adsorption capacity would not decrease significantly. Yuan et al. (2016) had grown the adsorbent formed by the thirdgeneration-PAMAM dendritic structure on superparamagnetic epoxy polymer composites by soap-free emulsion polymerization procedure to remove $\mathrm{U}^{6+}$, and the results showed that there was no significant loss of adsorption capacity after five adsorption cycles. All these reflect that polyamide-amines composite can achieve effective and regenerative effect in the removal of heavy metal ions.

\section{PAMAMs/Natural Clay Mineral Composites}

Natural clay minerals, such as attapulgite (ATP), palygorskite (PAL), kaolinite and halloysite, etc, that can remove various pollutants from water. And sometimes they will be more feasible and cheaper than synthetic nano-adsorbents (Fan et al., 2009; Gibson et al., 2011).

Among the existing clay adsorbent, palygorskite is an aquifer banded magnesium-aluminum silicate mineral with typical one-dimensional structure (Wu et al., 2017). In addition, PAL has a highly ordered pore structure and a higher specific surface area, which makes PAL show great potential in the adsorption of heavy metal ions. However, the general adsorption and ion exchange are non-specific, and the capacity of natural PAL is greatly reduced due to the strong competition of co-existing metal ions for the natural PAL active center. Furthermore, the PAL is easily reunited in solution, which limits the entry and diffusion of heavy metal ions, resulting in the decrease of adsorption performance (Chen et al., 2010; Deng et al., 2013). The organic functional group is processed to form specific adsorption sites on its surface to enhance the adsorption capacity and selectivity of PAL. Thus, PAMAMs were selected to modify the natural PAL. For example, Zhou et al. (2015) designed a range of novel PAMAMs dendrimer functionalized PAL adsorbents, which were used to adsorb $\mathrm{Pb}$ (II) in water solution. It showed a high density of aminoterminal groups in water. Zhang et al. (2019b) prepared a new PVDF/hyperbranched nano palygorskite composite membrane, and the experimental results showed that the prepared composite membrane presented a good binding ability to heavy metal ions. Halloysite is an abundant and novel nano-material with excellent properties of high specific surface area, which can be used in heavy metal wastewater treatment (Zhao et al., 2013; Makaremi et al., 2015). Moreover, after absorption, the halloysite can be regenerated by calcination (Hermawan et al., 2018). Halloysite can be modified with PAMAMs. For example, Cheng et al. (2019) loaded polyamide-amines (PAMAMs) on the surface of magnetic halloysite nanotubes (MHNTs) by one-step thiolacetylene click chemistry and obtained MHNTs-PAMAMs with high-density terminal amine groups for effective adsorption of $\mathrm{Pb}$ (II).

Attapulgite is 2:1-type layered chain clay minerals with rodlike morphology, large specific surface area, and suitable cation exchange capacity, which can be used in the research field of heavy metal ion adsorption. Due to its excellent stability and good modification properties, it is used as a solid adsorbent and carrier for polymers and organic compounds in many fields (Chen and Wang, 2007; Li et al., 2015). However, ATP crystal bundles are large and difficult to be evenly suspended in a solvent, which greatly limits its application. Therefore, modifying the surface of ATP is a good choice to improve its dispersion performance and adsorption efficiency. PAMAMs have attracted more and more attention because of their terminal amino-functional groups which can enhance the dispersion of ATP and improve the adsorption performance. For example, Qin et al. (2019) prepared a series of PAMAMs modified attapulgite (ATP) adsorbents (G1.0-G4.0 PAMAMs-ATP). The research results showed that the adsorption capacity was still $>90 \%$ after five cycles, so this material had the potential to be a highly efficient composite adsorbent for $\mathrm{Hg}^{2+}$ removal, and the Figure 6 presented the adsorption binding mechanism.

\section{PAMAMs/Silicon-Based Composites}

In recent times, silica has attracted attention in wastewater treatment for its good thermal and mechanical stability, excellent surface functionality, and high specific surface area (Zhao et al., 2018; Lelifajri and Nurfatimah, 2018). A great number of functional groups are used to modify silica to improve its adsorption capacity and selectivity (Kim et al., 2018). These include inorganic-organic hybrid materials, 


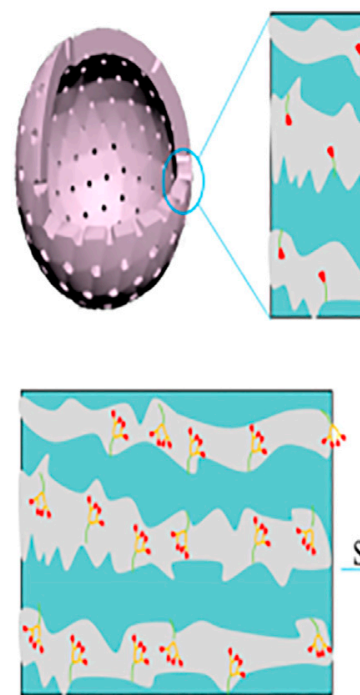

$\mathrm{Si0}-\mathrm{G} 2.0$

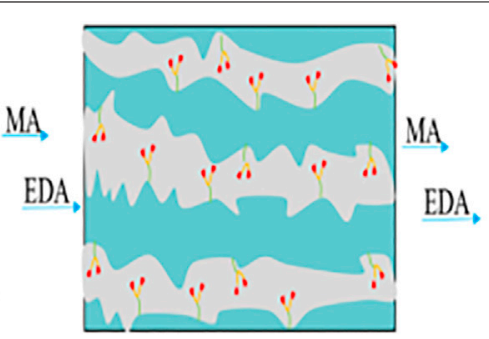

$\mathrm{SiO} 2 \cdot \mathrm{Gl} \cdot 0$
$\mathrm{SiO}:-\mathrm{G} 0$

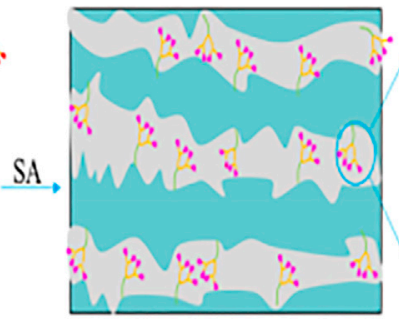

SG.G2.0-SA

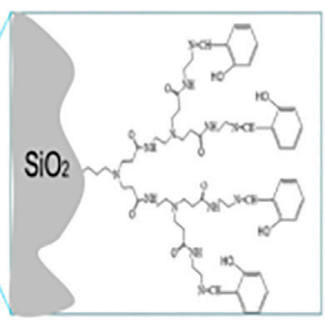

FIGURE 7 | The synthesis route for SG-G2.0-SA.

TABLE 3 | Heavy metal ions adsorption by polyamide amine/silicon-based composites.

\begin{tabular}{|c|c|c|c|c|c|}
\hline Adsorbents & Metal ions & $Q_{e}(\mathrm{mg} / \mathrm{g})$ & Conditions & Model (adsorption isotherm; kinetics) & References \\
\hline SG-G2.0 & $\begin{array}{l}\mathrm{Cd}^{2+} \\
\mathrm{Fe}^{3+}\end{array}$ & $\begin{array}{l}35.97 \\
13.40\end{array}$ & $\begin{array}{l}313 \mathrm{~K} ; \mathrm{pH} 5.5 ; \mathrm{C}_{0}=0.0015 \mathrm{~mol} / \mathrm{mL} \\
313 \mathrm{~K} ; \mathrm{pH} 5.5 ; \mathrm{C}_{0}=0.0015 \mathrm{~mol} / \mathrm{mL}\end{array}$ & $\begin{array}{l}\text { Langmuir isotherm model } \\
\text { Pseudo-second-order }\end{array}$ & Zhu et al. (2018) \\
\hline $\mathrm{SiO}_{2}-\mathrm{G} 2.0-\mathrm{MITC}$ & $\mathrm{Hg}^{2+}$ & 379.12 & $308 \mathrm{~K} ; \mathrm{pH} 6.0 ; \mathrm{C}_{0}=0.004 \mathrm{mmol} / \mathrm{L}$ & $\begin{array}{l}\text { Langmuir isotherm model } \\
\text { Pseudo-second-order }\end{array}$ & Niu et al. (2016) \\
\hline SG-MITC-G1.0 & $\mathrm{Ag}^{+}$ & 160.71 & 308K; pH 6.0; - & $\begin{array}{l}\text { Langmuir isotherm model } \\
\text { Pseudo-second-order }\end{array}$ & Zhang et al. (2018) \\
\hline $\mathrm{SiO}_{2}-\mathrm{G} 2.0$ & $\begin{array}{l}\mathrm{Fe}^{3+} \\
\mathrm{Ag}^{+}\end{array}$ & $\begin{array}{l}37.98 \\
70.11\end{array}$ & $\begin{array}{l}308 \mathrm{~K} ; \mathrm{pH} 6.0 ; \mathrm{C}_{0}=0.006 \mathrm{mmol} / \mathrm{L} \\
308 \mathrm{~K} ; \mathrm{pH} 6.0 ; \mathrm{C}_{0}=0.006 \mathrm{mmol} / \mathrm{L}\end{array}$ & $\begin{array}{l}\text { Langmuir isotherm model } \\
\text { Pseudo-second-order }\end{array}$ & Li et al. (2019) \\
\hline PAMAM-n.OSSASG & $\mathrm{Pd}^{2+}$ & 25.05 & $298 \mathrm{~K} ; \mathrm{pH} 6.0 ; \mathrm{C}_{0}=40.0 \mu \mathrm{g} / \mathrm{mL}$ & $\begin{array}{l}\text { Langmuir isotherm model } \\
\text { Pseudo-second-order }\end{array}$ & Wu et al. (2016) \\
\hline SG-G2.0-SA & $\begin{array}{l}\mathrm{Zn}^{2+} \\
\mathrm{Ni}^{2+}\end{array}$ & $\begin{array}{r}133.43 \\
58.69\end{array}$ & $\begin{array}{l}298 \mathrm{~K} ; \mathrm{pH} 6.0 ; \mathrm{C}_{0}=0.0048 \mathrm{~mol} / \mathrm{L} \\
298 \mathrm{~K} ; \mathrm{pH} 5.0 ; \mathrm{C}_{0}=0.0048 \mathrm{~mol} / \mathrm{L}\end{array}$ & $\begin{array}{l}\text { Langmuir isotherm model } \\
\text { Pseudo-second-order }\end{array}$ & Luan et al. (2021b) \\
\hline G-3PAMAMSGA & $\mathrm{Cd}^{2+}$ & 28.49 & $303 \mathrm{~K} ; \mathrm{pH} 5.0 ; \mathrm{C}_{0}=175 \mathrm{mg} / \mathrm{L}$ & $\begin{array}{l}\text { Freundlich isotherm model } \\
\text { Pseudo-second-order }\end{array}$ & Ebelegi et al. (2020) \\
\hline $\mathrm{SiO}_{2}$-dendrimers & $\mathrm{Cu}^{2+}$ & 104.6 & $301 \mathrm{~K} ; \mathrm{pH} 5.4 ; \mathrm{C}_{0}=10 \mathrm{mmol} / \mathrm{L}$ & $\begin{array}{l}\text { Langmuir isotherm model } \\
\text { Pseudo-first-order }\end{array}$ & $\begin{array}{l}\text { Pawlaczyk and } \\
\text { Schroeder, (2019) }\end{array}$ \\
\hline $\mathrm{SiO}_{2}-\mathrm{PAMAM}$ & $\begin{array}{l}\mathrm{Ni}^{2+} \\
\mathrm{Co}^{2+}\end{array}$ & $\begin{array}{l}116.6 \\
101.1\end{array}$ & $\begin{array}{l}298 \mathrm{~K} ; \mathrm{pH} 5.4 ; \mathrm{C}_{0}=15 \mathrm{mmol} / \mathrm{L} \\
298 \mathrm{~K} ; \mathrm{pH} 5.4 ; \mathrm{C}_{0}=15 \mathrm{mmol} / \mathrm{L}\end{array}$ & $\begin{array}{l}\text { Langmuir isotherm model } \\
\text { Pseudo-second-order }\end{array}$ & $\begin{array}{l}\text { Pawlaczyk and } \\
\text { Schroeder, (2020) }\end{array}$ \\
\hline PAMAM-SBA-15 & $\begin{array}{l}\mathrm{Cu}^{2+} \\
\mathrm{Pb}^{2+} \\
\mathrm{Cd}^{2+}\end{array}$ & $\begin{array}{l}110.58 \\
240.35 \\
109.04\end{array}$ & $\begin{array}{l}298 \mathrm{~K} ; \mathrm{pH} 4.0 ; \mathrm{C}_{0}=5 \mathrm{mmol} / \mathrm{L} \\
298 \mathrm{~K} ; \mathrm{pH} 5.0 ; \mathrm{C}_{0}=5 \mathrm{mmol} / \mathrm{L} \\
298 \mathrm{~K} ; \mathrm{pH} 5.0 ; \mathrm{C}_{0}=5 \mathrm{mmol} / \mathrm{L}\end{array}$ & $\begin{array}{l}\text { Langmuir isotherm model } \\
\text { Pseudo-second-order }\end{array}$ & $\begin{array}{l}\text { Shahbazi et al. } \\
(2013)\end{array}$ \\
\hline
\end{tabular}

which are inorganic carriers based on the functionalization of organic functional groups, which can also be represented by silica particles grafted by PAMAMs (Diagboya and Dikio, 2018). The functionalized PAMAMs/silica hybrids (as shown in Figure 7) exhibited superior adsorption property than the unmodified PAMAMs (Luan et al., 2021b). At present, polyamide-amine/silicon-based composite materials include the composite with silica gel (Wu et al., 2006; Qu et al., 2008a; Dey and Airoldi, 2008; Kumar and Guliants, 2010; Sun et al., 2011; Radi et al., 2016), mesoporous silica (Sayari et al.,
2015), and nano-silica particles (Pawlaczyk and Schroeder, 2019; Qiu et al., 2019; Ren et al., 2019; Ebelegi et al., 2020; Pawlaczyk and Schroeder, 2020; Qiao et al., 2020). The adsorption performance of PAMAMs/silicon-based composites for heavy metal ions $\left(\mathrm{Pb}^{2+}, \mathrm{Cu}^{2+}, \mathrm{Ni}^{2+}, \mathrm{Ag}^{+}, \mathrm{Fe}^{3+}\right.$, etc. $)$ is summarized in Table 3. These works indicate that the PAMAMs can be used to modify the silicon-based materials to improve their adsorption performance for heavy metals.

For example, Zhu et al. (2018) successfully synthesized amino-terminated PAMAMs supported on silica gel and 
realized the feasibility of removing heavy metal ions in dimethylsulfoxide (DMSO). At the same time, Li et al. (2019) also prepared a series of amine-terminated PAMAMs/silica gel hybrids for the adsorption of $\mathrm{Ag}(\mathrm{I})$ and $\mathrm{Fe}$ (III) from DMSO. A series of hyperbranched PAMAMs supported by silica was synthesized by Niu et al. (2013), Niu et al. (2014), Niu et al. (2016), Yin et al. (2019), and the adsorption properties for different heavy metals were investigated, such as lead, mercury, chromium, etc., which may be important for the remediation for the heavy metals pollution. Combining the experimental results with DFT calculations, its adsorption mechanism was explored. Zhang et al. (2018) prepared sulfur crown PAMAMs on silica gel, which could be used to adsorb Ag(I) in water. Wu et al. (2016) prepared dendrimer polyamide salicylaldehyde modified silica gel PAMAM-n.0SSASG $(n=1,2,3,4)$, and explored the performance of PAMAM-n.0SSASG microcolumn for separation and enrichment of Cd(II). Jiang et al. (2007) successfully prepared G4-PAMAM-SBA-15 that showed high selectivity for $\mathrm{Cr}^{3+}, \mathrm{Pb}^{2+}$ and $\mathrm{Zn}^{2+}$. Shahbazi et al. (2013) also prepared the functionalized SBA-15 mesoporous silica with polyamidoamine groups, which was used as an adsorbent to remove $\mathrm{Cd}$ (II), $\mathrm{Pb}$ (II), and $\mathrm{Cu}$ (II) ions from aqueous solutions, the research showed that the intermittent and column systems had distinct features, which can be further used to design adsorption systems to purify wastewater contaminated by heavy metal ions.

In general, the prepared PAMAMs/silicon-based composites are good adsorption material, which provides a good application prospect for heavy metal ion adsorption research. However, there are many factors that affect the adsorption materials. In the existed reports, the difference of adsorption of different ions by an adsorbent has not been explained in depth. The influence of the solvent system on the adsorption process still needs further research, and there is no report on the results of combining kinetic and thermodynamic data.

\section{PAMAMs/Titanium Dioxide Composites}

Porous titanium dioxide $\left(\mathrm{TiO}_{2}\right)$ is considered an ideal skeleton material for removing heavy metals because of its excellent chemical stability, low cost, versatility, non-toxicity (Correa et al., 2015; Hallam et al., 2021), and poor hydrolysis stability (Gewert et al., 2015). Functionalization of the surface titania via various anchoring groups for improving adsorption performance of heavy metals, such as silane, carboxylate, amino has been previously demonstrated (Pujari et al., 2014). Barakat et al. (2013a), Barakat et al. (2013b) immobilized G4.0 PAMAMs on titania to obtain novel metal chelation materials for removing heavy metals from aqueous solutions. Maleki et al., 2016) prepared $\mathrm{TiO}_{2}$ nanoparticles modified by G4.0 PAMAMs to remove heavy metals in industrial wastewater, and selected metal ions $\mathrm{Cu}$ (II), $\mathrm{Pb}$ (II), and $\mathrm{Cd}(\mathrm{II})$ as model pollutants. The results showed that the hybrid material was a good absorbent with high adsorption performance.

\section{THE PAMAMS COMPOSITES GRAFTED ORGANIC FUNCTIONAL GROUPS AND THEIR ADSORPTION FOR HEAVY METALS}

\section{PAMAMs Grafted Organic Small Molecular Materials}

The surface modification of PAMAMs by organic small molecules has attracted more and more attention due to the common elements such as alkaline and alkaline earth metals. For example, Zhou et al. (2019) prepared PAMAMs gel through PAMAMs and epichlorohydrin cross-linking reaction, and the maximum adsorption capacity for $\mathrm{Cr}(\mathrm{VI})$ got to $267.4 \mathrm{mg} / \mathrm{g}$. Ilaiyaraja et al. (2013a), Ilaiyaraja et al. (2013b), Priyadarshini and Ilaiyaraja (2019) prepared three novel chelating adsorbents (PAMAMG3-SDB, Diglycolamic acid (DGA)-PAMAM-SDB, and PAMAMG3), which were grown on the surface of styrene-diethylbenzene (SDB) by divergent polymerization and used as adsorbents for removing simulated nuclear liquid waste contained Th(IV) and U(VI), and the results showed that these chelating materials could be used as potential adsorbents. In the same year, xanthate functionalized dendrimers were synthesized by Ilaiyaraja et al. (2013c) for removing Co(III) ions from aqueous solution. Hernández Ramirez et al. (2015) prepared a novel metal-chelating porphyrin-PAMAM via the microwave method for removal of hazardous heavy metal ions. The results showed that the removal rate of $\mathrm{Pb}(\mathrm{II}), \mathrm{Cr}(\mathrm{II})$, and $\mathrm{Fe}(\mathrm{II})$ by the third-generation porphyrin PAMAMs could reach 99\%. In 2003, Rether and Schuster (2003) synthesized novel metal-chelating dendrimers from PAMAMs modified by benzoylthiourea, which can effectively remove heavy metal ions [Co(II), Pb(II), $\mathrm{Hg}(\mathrm{II}), \mathrm{Ni}(\mathrm{II}), \mathrm{Cu}(\mathrm{II})$, and $\mathrm{Zn}(\mathrm{II})]$. Su et al. (2012) prepared a series of PAMAMs dendrimer hydrophobic ionic liquid N-butyl-N-methylpyrrolidinium bis((trifluoromethyl) sulfonyl)-amide modified with polypyridine-type flexible small molecular ion-carriers or two rigid ionophores to extract $\mathrm{Cu}$ (II) ions from aqueous solution. However, the problem of poor selectivity of polypyridine-type modified PAMAMs remains to be solved.

\section{PAMAMs Grafted Organic Polymer Materials PAMAMs Grafted Synthetic Polymer Materials}

Among all kinds of adsorbents, polymer materials are widely used because of their rich raw materials, changeable product types, high functional group content, easy separation, and easy preservation, and play an important role in the removal of heavy metals. Therefore, there are many studies on their modification, and the heavy metals $\left(\mathrm{Cu}^{2+}, \mathrm{Hg}^{2+}, \mathrm{Ni}^{2+}\right.$, etc.) adsorption by polyamide-amines grafted organic polymer materials are summarized in Table 4. For example, Ju et al. (2019) had grown the hyperbranched PAMAMs molecular chain on the surface of polyacrylonitrile (PAN) to obtain the active center adsorbent of PAN-nG-PAMAM $(n=1.0,1.5,2.0,2.5,3.0)$ polyamine, and extracted $\mathrm{U}(\mathrm{VI})$ from seawater. The results illustrated that the maximum adsorption capacity of the 
TABLE 4 | Heavy metal ions adsorption by PAMAMs grafted organic materials.

\begin{tabular}{|c|c|c|c|c|c|}
\hline Adsorbents & Metal ions & $Q_{\mathrm{e}}(\mathrm{mg} / \mathrm{g})$ & Conditions & Model (adsorption isotherm; kinetics) & References \\
\hline PVDF-g-PAA-PAMAM & $\mathrm{Cu}^{2+}$ & 100.98 & 298K; pH 5.5; - & Lagergrensecond-order model & Sun et al. (2019) \\
\hline PAN-3G-PAMAM & $U^{6+}$ & 555.5 & $318 \mathrm{~K} ; \mathrm{pH} 5.0 ; \mathrm{C}_{0}=500 \mathrm{mg} / \mathrm{L}$ & $\begin{array}{l}\text { Langmuir isotherm model } \\
\text { Pseudo-second-order }\end{array}$ & Ju et al. (2019) \\
\hline PS-PAMAM-PPA & $U^{6+}$ & 99.89 & $298 \mathrm{~K} ; \mathrm{pH} 5.0 ; \mathrm{C}_{0}=100 \mathrm{mg} / \mathrm{L}$ & $\begin{array}{l}\text { Langmuir isotherm model } \\
\text { Pseudo-second-order }\end{array}$ & Cao et al. (2013) \\
\hline PS-PAMAM-IDA & $\mathrm{Ni}^{2+}$ & $24.09 \pm 1.79$ & $298 \mathrm{~K} ; \mathrm{pH} 7.0 ; \mathrm{C}_{0}=200 \mathrm{mg} / \mathrm{L}$ & $\begin{array}{l}\text { Langmuir isotherm model } \\
\text { Pseudo-first-order }\end{array}$ & Liu et al. (2014) \\
\hline CTS-1.0 & $\mathrm{Hg}^{2+}$ & 526.32 & $298 \mathrm{~K} ; \mathrm{pH} 5.0 ; \mathrm{C}_{0}=2005.9 \mathrm{mg} / \mathrm{L}$ & $\begin{array}{l}\text { Langmuir isotherm model } \\
\text { Pseudo-second-order }\end{array}$ & Ma et al. (2009) \\
\hline HPFC & $\mathrm{Cu}^{2+}$ & 155 & 318K; pH 8.3; $\mathrm{C}_{0}=1,200$ mg/L & $\begin{array}{l}\text { Langmuir isotherm model } \\
\text { Pseudo-second-order }\end{array}$ & Yu et al. (2019) \\
\hline G4PSt & $\mathrm{Cu}^{2+}$ & 251.19 & $303 \mathrm{~K} ; \mathrm{pH} 5.5 ; \mathrm{C}_{0}=20 \mathrm{mmol} / \mathrm{L}$ & $\begin{array}{l}\text { Langmuir isotherm model } \\
\text { Pseudo-second-order }\end{array}$ & Zhang et al. (2021) \\
\hline
\end{tabular}

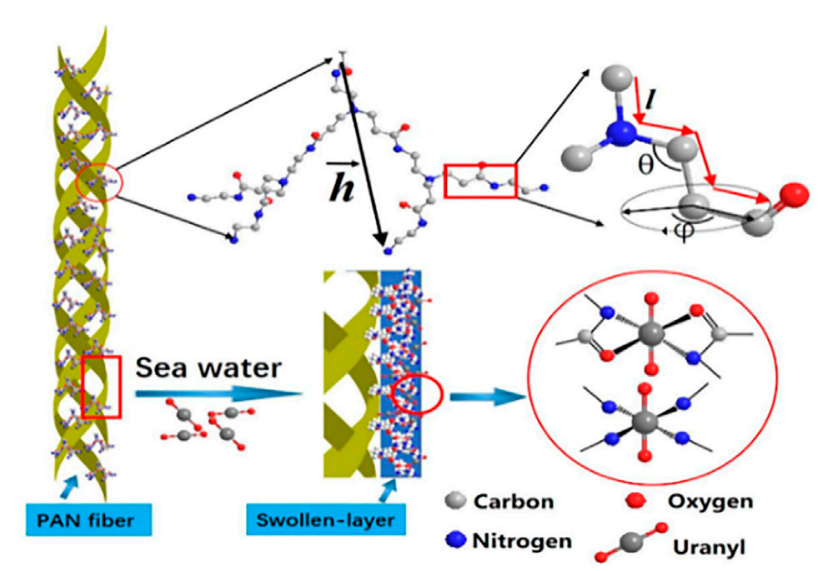

FIGURE 8 | Adsorption mechanism of U(VI) by PAN-nG-PAMAM.

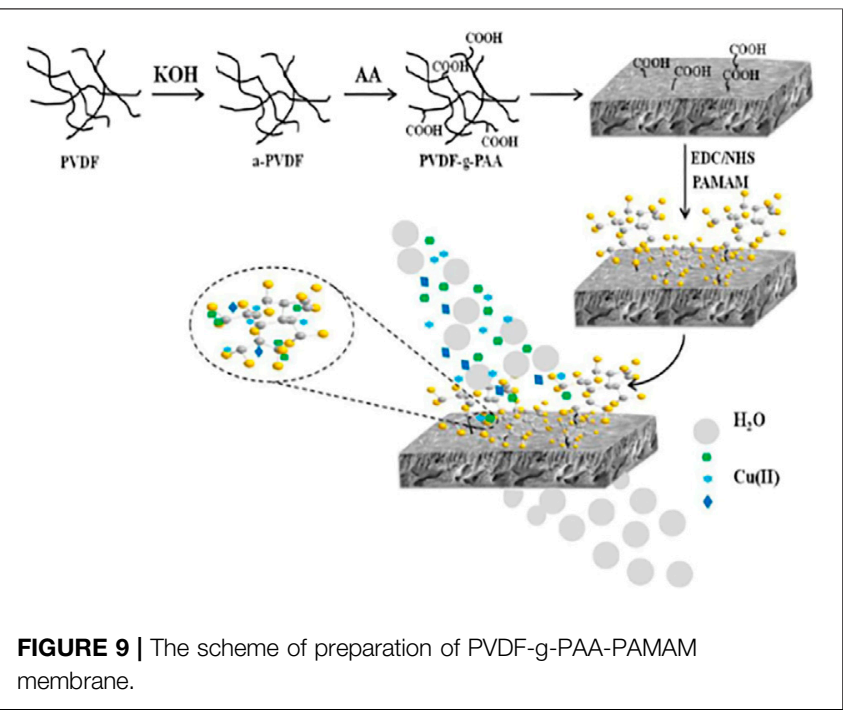

adsorbent reached $555.5 \mathrm{mg} / \mathrm{g}$ and the adsorption mechanism of U(VI) by PAN-nG-PAMAMs is shown in Figure 8. The PAMAMs modified poly (styrene-co-divinylbenzene) (PS-PAMAM-PPA) was used to adsorb $\mathrm{U}(\mathrm{VI})$ from aqueous solution (Cao et al.,
2013) and the adsorption and desorption researches indicated that it could be reused 27 cycles. Liu et al., 2014) prepared lowgeneration polyamide-amines chelating resins (PS-PAMAMIDA) to preconcentrate $\mathrm{Ni}^{2+}$ from synthetic aqueous samples. The study confirmed the feasibility of the chelation reaction between nickel ion and synthetic resin. Diallo et al. (2008) had also done relevant research to recover $\mathrm{U}(\mathrm{VI})$ from wastewater.

Polyvinylidene fluoride (PVDF) membrane is widely used because of its excellent mechanical strength, acid and alkali resistance, thermal stability, and low cost. However, since the structure of the PVDF membrane does not contain functional groups $\left(-\mathrm{NH}_{2},-\mathrm{COOH},-\mathrm{OH}\right.$, etc.) that can complex with heavy metal ions, the ability to adsorb heavy metal ions is usually improved by introducing some functional groups (Chen et al., 2018). For example, Sun et al. (2019) synthesized PVDF-GPAA-PAMAM composite membrane by grafting different generations of polyamide-amines onto PVDF-G-PAA membranes (as shown in Figure 9). The composite membrane had good adsorption performance for $\mathrm{Cu}$ (II) ions, and the adsorption capacity could reach $100.98 \mathrm{mg} / \mathrm{g}$, which was higher than that of pure PVDF membrane $(2.8 \mathrm{mg} / \mathrm{g})$. And after five desorption cycles, the regeneration rate of PVDF-g-PAA-PAMAM membranes was higher than $90 \%$, which had excellent recovery performance. The desorption experiments showed that PVDF-g-PAA-PAMAM membranes had excellent recycling performance. Kotte et al. (2015) prepared a novel mixed matrix polyvinylidene fluoride (PVDF) composites membrane via one-pot method, which contained in situ synthesized polyamide-amines (PAMAMs) particles, and investigated its adsorption performance for $\mathrm{Cu}(\mathrm{II})$. The present experiment shows that the mixed matrix PVDF membranes can act as a novel high-capacity adsorbent to recover $\mathrm{Cu}(\mathrm{II})$ from aqueous solution. These studies proved that the modification of PAMAMs was beneficial to the adsorption of $\mathrm{Cu}(\mathrm{II})$, laying a certain foundation for the practical application of the PAMAMs modified PVDF membrane in the treatment of wastewater containing $\mathrm{Cu}(\mathrm{II})$.

\section{PAMAMs Grafted Natural Organic Polymer Material}

Chitosan (CTS) is a basic deacetylated product of chitin, which is widely used due to its hydrophilic, non-toxic, easy degradation, 
and biocompatibility (Chatterjee et al., 2005). A large number of highly active hydroxyl and amino groups exist on the surface of chitosan, which can be used as adsorption sites. However, its low porosity, softness, and tendency to aggregate and form gel has some disadvantages in the treatment process of wastewater (Evans et al., 2002). Physical or chemical modification of chitosan can improve its chemical and mechanical properties. In recent years, the surface chemical modification of chitosan with certain functional groups has attracted extensive attention, because it can significantly improve the stability of chitosan in acidic media and improve its selective adsorption for heavy metal ions (Sun et al., 2006; Donia et al., 2008). Many new functional materials will be obtained by introducing polymer into chitosan. For example, Ma et al. (2009) synthesized the ester and amino-terminated chitosan of dendritic PAMAMs polymer (CTS-1.0-3.0) by divergent method and studied the adsorption behavior of $\mathrm{Hg}$ (II) on the adsorbent in their previous work, they also studied the competitive adsorption of different heavy metals $\left(\mathrm{Au}^{3+}, \mathrm{Pt}^{4+}, \mathrm{Pd}^{2+}, \mathrm{Cu}^{2+}\right.$, $\mathrm{Ni}^{2+}, \mathrm{Ag}^{+}, \mathrm{Zn}^{2+}, \mathrm{Hg}^{2+}$, and $\mathrm{Cd}^{2+}$ ) on similar compounds, and the results showed that the adsorption capacity of $\mathrm{Au}^{3+}$ and $\mathrm{Hg}^{2+}$ was stronger than that of other metal ions (Qu et al., 2008b). Zarghami et al. (2016) successfully synthesized different generations of PAMAMs grafted chitosan as a comprehensive biological adsorbent (CS-G0.5 G5.0) via step by step divergent growth method, and studied the adsorption performance of heavy metals $\left(\mathrm{Pb}^{2+}\right)$ in water. The results showed that the adsorption capacity of CS-G3.0 for $\mathrm{Pb}$ (II) was 18 times that of single chitosan.

Cellulose is one of the most abundant natural polymers in the world (Zhou et al., 2013), which has attracted extensive attention because of its richness, sustainability, and easy functionalization. However, the surface area of raw cellulose is not high and the density of binding sites is relatively low, so the adsorption capacity for heavy metal ions is usually not satisfactory (Klemm et al., 2011; Hokkanen et al., 2016; Tao et al., 2017). Therefore, cellulose can be converted into efficient adsorbents by introducing some functional groups with an affinity for metal ions, such as amino, carboxyl, sulfonic and hydroxyl groups (Jin et al., 2017). Existing studies revealed that the composites formed by the combination of cellulose and functional polymers have excellent pollutant adsorption capacity. For example, Yu et al. (2019) synthesized an amino terminated hyperbranched polyamide-amines functionalized cellulose adsorbent for effective removal of dyes and metal ions, and the material shows excellent adsorption for $\mathrm{Cu}(\mathrm{II})$. Similarly, Wang and Lu (2019) prepared a series of PAMAMs functionalized nanocrystalline cellulose composites to measure the effect of removing $\mathrm{Cu}$ (II) from aqueous solution. Ilaiyaraja (Zhao et al., 2015) synthesized a novel polyamide-amine-grafted cellulose nanofibrils aerogel for the removal of $\mathrm{Cr}(\mathrm{VI})$ and the results showed that the maximum removal rate of $\mathrm{Cr}(\mathrm{VI})$ reached $377.36 \mathrm{mg} / \mathrm{g}$, which was the highest value of $\mathrm{Cr}(\mathrm{VI})$ removal by a biosorbent since it was reported. The modification of corncob and soy hull containing a lot of cellulose in crops was also investigated. Zhang et al. (2016b) prepared PAMAMs functionalized soybean shell (PDFSH) for adsorbing rare earth metal ions $\left(\mathrm{La}^{3+}, \mathrm{Nd}^{3+}\right.$ and $\left.\mathrm{Sm}^{3+}\right)$ from aqueous solution. Lin et al. (2017), Lin et al. (2018) synthesized a low-cost anionic adsorbent (HPMC) to effectively remove $\mathrm{Cr}$ (VI) by modifying corn cobs with hyperbranched PAMAMs, the PAMAMs grafted cellulose had become a very promising adsorbent for the efficient and rapid treatment of some toxic metal pollutants.

Starch is a kind of abundant, renewable, and degradable natural biological material, which can combine with a variety of compounds through physical and chemical actions (Dong et al., 2010). In recent years, modified starch had been used as a heavy metal ion absorbent by introducing substances containing various active groups, such as aminothiazole, acrylonitrile, phosphate, carboxylate, etc (Zhang et al., 2008). For example, Zhang et al. (2021) prepared polyamidomine dendrimer starch with epichlorohydrin as a cross-linking agent, which was used to effectively remove heavy metals and provides a basis for the study of $\mathrm{Cu}$ (II) and $\mathrm{Zn}$ (II) adsorption.

\section{CONCLUSION}

PAMAMs can introduce a large number of functional groups, which have achieved good research results in the treatment of wastewater containing heavy metal ions. In the paper, the preparation of the composites based on PAMAMs and inorganic functional component or organic functional groups and its application on the adsorption of heavy metals were reviewed. The adsorption behavior and properties of PAMAMs composites are summarized as follows: firstly, reasonable modification or adjustment of functional groups (including $\mathrm{N}$, $\mathrm{O}$ and $\mathrm{S}$ functional groups) on the required components is one of the effective strategies to improve the adsorption properties of PAMAMs composites, secondly, the stability of the composite material is improved, and its flocculation effect is improved under acidic conditions. Meanwhile, Langmuir isothermal model and Pseudo-second-order kinetic model can better describe the adsorption data, and most of the adsorption processes are spontaneous and endothermic. In addition, the results of desorption and reuse show that PAMAMs can achieve excellent regeneration effect in removing heavy metal ions.

Although plummy progress has been obtained at this stage, there are still many challenges in the future with the deepening of research. For example, the synthesis process of PAMAMs is complex and the separation process is cumbersome, which limits its further large-scale industrial application in the removal of industrial wastewater. At present, there is still a shortage of numerical models to study the adsorption behavior of heavy metal ions by PAMAMs composites in solution and the molecular interaction mechanism between PAMAMs composites and heavy metal ions are still poorly understood. The effect of solvent system on the adsorption process and its specific adsorption performance during the treatment of heavy metal ions and dye wastewater still needs further study.

The future research direction can be started from the following aspects: the adsorption performance of PAMAMs composites is further improved by optimizing the adsorption reasonably, reducing the cost, simplifying the preparation process and increasing the functionalization pathway. Apart from that, the binding mechanism of PAMAMs composite with metal ions is explored according to the numerical model. All the aspects are the key direction in the future. 


\section{AUTHOR CONTRIBUTIONS}

QW performed the writing of the original draft, managing resources and analyzing information. FZ performed the review and editing. All authors read and approved the final manuscript.

\section{REFERENCES}

Aguado, J., Arsuaga, J. M., Arencibia, A., Lindo, M., and Gascón, V. (2009). Aqueous Heavy Metals Removal by Adsorption on Amine-Functionalized Mesoporous Silica. J. Hazard. Mater. 163 (1), 213-221. doi:10.1016/j.jhazmat.2008.06.080

Astruc, D., and Chardac, F. (2001). Dendritic Catalysts and Dendrimers in Catalysis. Chem. Rev. 101 (9), 2991-3024. doi:10.1021/cr010323t

Baghayeri, M., Amiri, A., Karimabadi, F., Di Masi, S., Maleki, B., Adibian, F., et al. (2021). Magnetic MWCNTs-Dendrimer: A Potential Modifier for Electrochemical Evaluation of as (III) Ions in Real Water Samples. J. Electroanalytical Chem. 888, 115059. doi:10.1016/j.jelechem.2021.115059

Barakat, M. A., Ramadan, M. H., Kuhn, J. N., and Woodcock, H. L. (2013). Equilibrium and Kinetics of $\mathrm{Pb}^{2+}$ Adsorption from Aqueous Solution by Dendrimer/titania Composites. Desalin Water Treat. 52 (31-33), 5869-5875. doi:10.1080/19443994.2013.815584

Barakat, M. A., Ramadan, M. H., Alghamdi, M. A., Algarny, S. S., Woodcock, H. L., and Kuhn, J. N. (2013). Remediation of $\mathrm{Cu}(\mathrm{II}), \mathrm{Ni}(\mathrm{II})$, and $\mathrm{Cr}(\mathrm{III})$ Ions from Simulated Wastewater by Dendrimer/titania Composites. J. Environ. Manage. 117, 50-57. doi:10.1016/j.jenvman.2012.12.025

Cao, Q., Liu, Y., Wang, C., and Cheng, J. (2013). Phosphorus-modified Poly(styrene-Co-Divinylbenzene)-PAMAM Chelating Resin for the Adsorption of Uranium(VI) in Aqueous. J. Hazard. Mater. 263 (2), 311-321. doi:10.1016/j.jhazmat.2013.05.039

Chatterjee, S., Adhya, M., Guha, A. K., and Chatterjee, B. P. (2005). Chitosan from Mucor Rouxii: Production and Physico-Chemical Characterization. Process Biochem. 40 (1), 395-400. doi:10.1016/j.procbio.2004.01.025

Chen, H., and Wang, A. (2007). Kinetic and Isothermal Studies of lead Ion Adsorption onto Palygorskite clay. J. Colloid Interf. Sci. 307 (2), 309-316. doi:10.1016/j.jcis.2006.10.054

Chen, M., Shafer-Peltier, K., Randtke, S. J., and Peltier, E. (2018). Competitive Association of Cations with Poly(sodium 4-styrenesulfonate) (PSS) and Heavy Metal Removal from Water by PSS-Assisted Ultrafiltration. Chem. Eng. J. 344, 155-164. doi:10.1016/j.cej.2018.03.054

Chen, Y., Pan, B., Li, H., Zhang, W., Lv, L., and Wu, J. (2010). Selective Removal of $\mathrm{Cu}$ (II) Ions by Using Cation-Exchange Resin-Supported Polyethyleneimine (PEI) Nanoclusters. Environ. Sci. Technol. 44 (9), 3508-3513. doi:10.1021/ es100341x

Chen, Z., Tang, B., Niu, Y., Chen, H., Liu, Y., Wang, A., et al. (2021). Synthesis of Silica Supported Thiosemicarbazide for $\mathrm{Cu}(\mathrm{II})$ and $\mathrm{Zn}(\mathrm{II})$ Adsorption from Ethanol: A Comparison with Aqueous Solution. Fuel 286, 119287. doi:10.1016/ j.fuel.2020.119287

Cheng, D., Dai, X., Chen, L., Cui, Y., Qiang, C., Sun, Q., et al. (2019). Thiol-Yne Click Synthesis of Polyamide-Amine Dendritic Magnetic Halloysite Nanotubes for the Efficient Removal of $\mathrm{Pb}(\mathrm{II})$. ACS Sustain. Chem. Eng. 8 (2), 771-781. doi:10.1021/acssuschemeng.9b04135

Correa, G. C., Bao, B., and Strandwitz, N. C. (2015). Chemical Stability of Titania and Alumina Thin Films Formed by Atomic Layer Deposition. ACS Appl. Mater. Inter. 7 (27), 14816-14821. doi:10.1021/acsami.5b03278

Deng, Y., Gao, Z., Liu, B., Hu, X., Wei, Z., and Sun, C. (2013). Selective Removal of lead from Aqueous Solutions by Ethylenediamine-Modified Attapulgite. Chem. Eng. J. 223, 91-98. doi:10.1016/j.cej.2013.03.020

Dey, R. K., and Airoldi, C. (2008). Designed Pendant Chain Covalently Bonded to Silica Gel for Cation Removal. J. Hazard. Mater. 156 (1-3), 95-101. doi:10.1016/ j.jhazmat.2007.12.005

Diagboya, P. N. E., and Dikio, E. D. (2018). Silica-based Mesoporous Materials; Emerging Designer Adsorbents for Aqueous Pollutants Removal and Water Treatment. Microporous Mesoporous Mater. 266, 252-267. doi:10.1016/j. micromeso.2018.03.008

\section{FUNDING}

The work was supported by Natural Science Foundation of Hunan Province (2020JJ4509), Key Projects of the Education Department of Hunan Province (21A0345) and Special scientific innovation project from Jishou University (JGY 202086), P. R. China.

Diallo, M. S., Arasho, W., Johnson, J. H., and Goddard III, W. A. (2008). Dendritic Chelating Agents. 2. U(VI) Binding to Poly(amidoamine) and Poly(propyleneimine) Dendrimers in Aqueous Solutions. Environ. Sci. Technol. 42 (5), 1572-1579. doi:10.1021/es0715905

Dong, A., Xie, J., Wang, W., Yu, L., Liu, Q., and Yin, Y. (2010). A Novel Method for Amino Starch Preparation and its Adsorption for $\mathrm{Cu}(\mathrm{II})$ and $\mathrm{Cr}(\mathrm{VI})$. J. Hazard. Mater. 181 (1-3), 448-454. doi:10.1016/j.jhazmat.2010.05.031

Donia, A. M., Atia, A. A., and Elwakeel, K. Z. (2008). Selective Separation of Mercury(II) Using Magnetic Chitosan Resin Modified with Schiffs Base Derived from Thiourea and Glutaraldehyde. J. Hazard. Mater. 151 (2-3), 372-379. doi:10.1016/j.jhazmat.2007.05.083

Ebelegi, A. N., Ayawei, N., Inengite, A. K., and Wankasi, D. (2020). Generation-3 Polyamidoamine Dendrimer-Silica Composite: Preparation and Cd(II) Removal Capacity. J. Chem. 2020, 1-11. doi:10.1155/2020/ 6662402

Einollahi Peer, F., Bahramifar, N., and Younesi, H. (2018). Removal of Cd (II), Pb (II) and Cu (II) Ions from Aqueous Solution by Polyamidoamine Dendrimer Grafted Magnetic Graphene Oxide Nanosheets. J. Taiwan Inst. Chem. Eng. 87, 225-240. doi:10.1016/j.jtice.2018.03.039

Ekinci, S., İlter, Z., Ercan, S., Çınar, E., and Çakmak, R. (2021). Magnetite Nanoparticles Grafted with Murexide-Terminated Polyamidoamine Dendrimers for Removal of lead (II) from Aqueous Solution: Synthesis, Characterization, Adsorption and Antimicrobial Activity Studies. Heliyon 7 (3), e06600. doi:10.1016/j.heliyon.2021.e06600

Evans, J. R., Davids, W. G., MacRae, J. D., and Amirbahman, A. (2002). Kinetics of Cadmium Uptake by Chitosan-Based Crab Shells. Water Res. 36 (13), 3219-3226. doi:10.1016/s0043-1354(02)00044-1

Fan, Q. H., Tan, X. L., Li, J. X., Wang, X. K., Wu, W. S., and Montavon, G. (2009). Sorption of Eu(III) on Attapulgite Studied by Batch, XPS, and EXAFS Techniques. Environ. Sci. Technol. 43 (15), 5776-5782. doi:10.1021/ es901241f

Feng, D., Zhang, Y., Zhao, Y., Sun, S., Wu, J., and Tan, H. (2020). Mechanism of InSitu Dynamic Catalysis and Selective Deactivation of $\mathrm{H}_{2} \mathrm{O}$-Activated Biochar for Biomass Tar Reforming. Fuel 279, 118450. doi:10.1016/j.fuel.2020.118450

Gewert, B., Plassmann, M. M., and MacLeod, M. (2015). Pathways for Degradation of Plastic Polymers Floating in the marine Environment. Environ. Sci. Process. Impacts 17 (9), 1513-1521. doi:10.1039/c5em00207a

Gibson, B. D., Ptacek, C. J., Lindsay, M. B. J., and Blowes, D. W. (2011). Examining Mechanisms of Groundwater $\mathrm{Hg}(\mathrm{II})$ Treatment by Reactive Materials: an EXAFS Study. Environ. Sci. Technol. 45 (24), 10415-10421. doi:10.1021/ es $202253 \mathrm{~h}$

Gupta, N. K., Sengupta, A., Boda, A., Adya, V. C., and Ali, S. M. (2016). Oxidation State Selective Sorption Behavior of Plutonium Using N,N-dialkylamide Functionalized Carbon Nanotubes: Experimental Study and DFT Calculation. RSC Adv. 6 (82), 78692-78701. doi:10.1039/c6ra17773e

Hadavifar, M., Bahramifar, N., Younesi, H., and Li, Q. (2014). Adsorption of Mercury Ions from Synthetic and Real Wastewater Aqueous Solution by Functionalized Multi-Walled Carbon Nanotube with Both Amino and Thiolated Groups. Chem. Eng. J. 237, 217-228. doi:10.1016/j.cej.2013.10.014

Hallam, L., Papasergio, A. E., Lessio, M., and Veliscek-Carolan, J. (2021). Phosphate Functionalised Titania for Heavy Metal Removal from Acidic Sulfate Solutions. J. Colloid Interf. Sci. 600, 719-728. doi:10.1016/j.jcis.2021. 05.047

Hawker, C. J., and Frechet, J. M. J. (1990). Control of Surface Functionality in the Synthesis of Dendritic Macromolecules Using the Convergent-Growth Approach. Macromolecules 23 (21), 4726-4729. doi:10.1021/ma00223a036

Hayati, B., Maleki, A., Najafi, F., Daraei, H., Gharibi, F., and McKay, G. (2017). Super High Removal Capacities of Heavy Metals $\left(\mathrm{Pb}^{2+}\right.$ and $\left.\mathrm{Cu}^{2+}\right)$ Using CNT Dendrimer. J. Hazard. Mater. 336, 146-157. doi:10.1016/j.jhazmat.2017.02.059 
Hayati, B., Maleki, A., Najafi, F., Gharibi, F., McKay, G., Gupta, V. K., et al. (2018). Heavy Metal Adsorption Using PAMAM/CNT Nanocomposite from Aqueous Solution in Batch and Continuous Fixed Bed Systems. Chem. Eng. J. 346, 258-270. doi:10.1016/j.cej.2018.03.172

Hermawan, A. A., Chang, J. W., Pasbakhsh, P., Hart, F., and Talei, A. (2018). Halloysite Nanotubes as a fine Grained Material for Heavy Metal Ions Removal in Tropical Biofiltration Systems. Appl. Clay Sci. 160, 106-115. doi:10.1016/j. clay.2017.12.051

Hernández Ramirez, R. E., Lijanova, I. V., Likhanova, N. V., and Xometl, O. O. (2015). PAMAM Dendrimers with Porphyrin Core: Synthesis and MetalChelating Behavior. J. Incl. Phenom. Macro. 84 (1-2), 49-60. doi:10.1007/ s10847-015-0582-z

Hokkanen, S., Bhatnagar, A., and Sillanpää, M. (2016). A Review on Modification Methods to Cellulose-Based Adsorbents to Improve Adsorption Capacity. Water Res. 91, 156-173. doi:10.1016/j.watres.2016.01.008

Ihsanullah, F. A., Al-Khaldi, F. A., Abusharkh, B., Khaled, M., Atieh, M. A., Nasser, M. S., et al. (2015). Adsorptive Removal of Cadmium(II) Ions from Liquid Phase Using Acid Modified Carbon-Based Adsorbents. J. Mol. Liquids 204, 255-263. doi:10.1016/j.molliq.2015.01.033

Iijima, S. (1991). Helical Microtubules of Graphitic Carbon. Nature 354, 56-58. doi:10.1038/354056a0

Ilaiyaraja, P., Deb, A. K. S., Sivasubramanian, K., Ponraju, D., and Venkatraman, B. (2013). Removal of Cobalt from Aqueous Solution Using Xanthate Functionalized Dendrimer. Desalin. Water Treat. 52 (1-3), 438-445. doi:10. 1080/19443994.2013.808454

Ilaiyaraja, P., Deb, A. K. S., Sivasubramanian, K., Ponraju, D., and Venkatraman, B. (2013). Removal of Thorium from Aqueous Solution by Adsorption Using PAMAM dendron-functionalized Styrene Divinyl Benzene. J. Radioanal. Nucl. Chem. 297 (1), 59-69. doi:10.1007/s10967-012-2402-x

Ilaiyaraja, P., Singha Deb, A. K., Sivasubramanian, K., Ponraju, D., and Venkatraman, B. (2013). Adsorption of Uranium from Aqueous Solution by PAMAM dendron Functionalized Styrene Divinylbenzene. J. Hazard. Mater. 250-251, 155-166. doi:10.1016/j.jhazmat.2013.01.040

Jiang, Y., Gao, Q., Yu, H., Chen, Y., and Deng, F. (2007). Intensively Competitive Adsorption for Heavy Metal Ions by PAMAM-SBA-15 and EDTA-PAMAMSBA-15 Inorganic-Organic Hybrid Materials. Micropor Mesopor Mater. 103 (13), 316-324. doi:10.1016/j.micromeso.2007.02.024

Jin, X., Xiang, Z., Liu, Q., Chen, Y., and Lu, F. (2017). Polyethyleneimine-bacterial Cellulose Bioadsorbent for Effective Removal of Copper and lead Ions from Aqueous Solution. Bioresour. Tech. 244 (1), 844-849. doi:10.1016/j.biortech. 2017.08.072

Ju, P., Liu, Q., Zhang, H., Chen, R., Liu, J., Yu, J., et al. (2019). Hyperbranched Topological Swollen-Layer Constructs of Multi-Active Sites Polyacrylonitrile (PAN) Adsorbent for Uranium(VI) Extraction from Seawater. Chem. Eng. J. 374, 1204-1213. doi:10.1016/j.cej.2019.05.222

Kido, Y., Nakanishi, K., Miyasaka, A., and Kanamori, K. (2012). Synthesis of Monolithic Hierarchically Porous Iron-Based Xerogels from Iron(III) Salts via an Epoxide-Mediated Sol-Gel Process. Chem. Mater. 24 (11), 2071-2077. doi:10.1021/cm300495j

Kim, S., Park, S., Han, S., Han, Y., and Park, J. (2018). Silanol-rich Ordered Mesoporous Silica Modified Thiol Group for Enhanced Recovery Performance of $\mathrm{Au}(\mathrm{III})$ in Acidic Leachate Solution. Chem. Eng. J. 351, 1027-1037. doi:10. 1016/j.cej.2018.06.136

Klemm, D., Kramer, F., Moritz, S., Lindström, T., Ankerfors, M., Gray, D., et al. (2011). Nanocellulosen: eine neue Familie naturbasierter Materialien. Angew. Chem. 123 (24), 5550-5580. doi:10.1002/ange.201001273

Kommu, A., Velachi, V., Cordeiro, M. N. D. S., and Singh, J. K. (2017). Removal of $\mathrm{Pb}$ (II) Ion Using PAMAM Dendrimer Grafted Graphene and Graphene Oxide Surfaces: A Molecular Dynamics Study. J. Phys. Chem. A. 121 (48), 9320-9329. doi:10.1021/acs.jpca.7b09766

Kong, Q., Shi, X., Ma, W., Zhang, F., Yu, T., Zhao, F., et al. (2021). Strategies to Improve the Adsorption Properties of Graphene-Based Adsorbent towards Heavy Metal Ions and Their Compound Pollutants: A Review. J. Hazard. Mater. 415, 125690. doi:10.1016/j.jhazmat.2021.125690

Kotte, M. R., Kuvarega, A. T., Cho, M., Mamba, B. B., and Diallo, M. S. (2015). Mixed Matrix PVDF Membranes with In Situ Synthesized PAMAM Dendrimer-like Particles: A New Class of Sorbents for $\mathrm{Cu}(\mathrm{II})$ Recovery from Aqueous Solutions by Ultrafiltration. Environ. Sci. Technol. 49 (16), 9431-9442. doi:10.1021/acs.est.5b01594

Kumar, P., and Guliants, V. V. (2010). Periodic Mesoporous Organic-Inorganic Hybrid Materials: Applications in Membrane Separations and Adsorption. Micropor. Mesopor. Mat. 132 (1-2), 1-14. doi:10.1016/j.micromeso.2010.02.007

Lard, M., Kim, S. H., Lin, S., Bhattacharya, P., Ke, P. C., and Lamm, M. H. (2010). Fluorescence Resonance Energy Transfer between Phenanthrene and PAMAM Dendrimers. Phys. Chem. Chem. Phys. 12 (32), 9285-9291. doi:10.1039/ b924522g

Lelifajri, R., and Nurfatimah, R. (2018). Preparation of Polyethylene Glycol Diglycidyl Ether (PEDGE) Crosslinked Chitosan/activated Carbon Composite Film for $\mathrm{Cd}^{2+}$ Removal. Carbohydr. Polym. 199, 499-505. doi:10. 1016/j.carbpol.2018.07.051

Li, H., Niu, Y., Xue, Z., Mu, Q., Wang, K., Qu, R., et al. (2019). Adsorption Property and Mechanism of PAMAM Dendrimer/silica Gel Hybrids for Fe(III) and Ag(I) from N,N-dimethylformamide. J. Mol. Liquids 273, 305-313. doi:10. 1016/j.molliq.2018.10.039

Li, S., Wei, Y., Kong, Y., Tao, Y., Yao, C., and Zhou, R. (2015). Electrochemical Removal of lead Ions Using Paper Electrode of Polyaniline/attapulgite Composites. Synth. Met. 199, 45-50. doi:10. 1016/j.synthmet.2014.11.003

Li, Y., Yu, H., Liu, L., and Yu, H. (2021). Application of Co-pyrolysis Biochar for the Adsorption and Immobilization of Heavy Metals in Contaminated Environmental Substrates. J. Hazard. Mater. 420, 126655. doi:10.1016/j. jhazmat.2021.126655

Liang, X., Ge, Y., Wu, Z., and Qin, W. (2017). DNA Fragments Assembled on Polyamidoamine-Grafted Core-Shell Magnetic Silica Nanoparticles for Removal of Mercury(II) and Methylmercury(I). J. Chem. Technol. Biotechnol. 92 (4), 819-826. doi:10.1002/jctb.5065

Lin, H., Han, S., Dong, Y., and He, Y. (2017). The Surface Characteristics of Hyperbranched Polyamide Modified Corncob and its Adsorption Property for Cr(VI). Appl. Surf. Sci. 412, 152-159. doi:10.1016/j.apsusc.2017.03.061

Lin, H., Han, S., Dong, Y., Ling, W., and He, Y. (2018). Structural Characteristics and Functional Properties of Corncob Modified by Hyperbranched Polyamide for the Adsorption of Cr (VI). Water Air Soil Pollut. 229 (4), 117. doi:10.1007/ s11270-018-3764-7

Ling, C., Ren, Z., Wei, M., Tong, F., Cheng, Y., Zhang, X., et al. (2020). Highly Selective Removal of $\mathrm{Ni}(\mathrm{II})$ from Plating Rinsing Wastewaters Containing [Ni$\left.\mathrm{xNH}_{3}-\mathrm{yP}_{2} \mathrm{O}_{7}\right]^{\mathrm{n}}$ Complexes Using N-Chelating Resins. J. Hazard. Mater. 398, 122960. doi:10.1016/j.jhazmat.2020.122960

Liu, C. H., Gao, C., and Yan, D. Y. (2005). Aliphatic Hyperbranched Poly (Amido Amine) S (PAMAMs): Preparation and Modification. Chem. Res. Chin. U 21 (3), 345 .

Liu, H., Zhang, F., and Peng, Z. (2019). Adsorption Mechanism of Cr(VI) onto GO/ PAMAMs Composites. Sci. Rep. 9 (1), 3663. doi:10.1038/s41598-019-40344-9

Liu, Y. C., Li, X. N., Wang, C. Z., Kong, X., and Zhong, L. Z. (2014). Poly(styreneco-divinylbenzene)-PAMAM-IDA Chelating Resin: Synthesis, Characterization and Application for $\mathrm{Ni}(\mathrm{II})$ Removal in Aqueous. J. Cent. South. Univ. 21 (9), 3479-3484. doi:10.1007/s11771-014-2325-5

Lotfi, Z., Mousavi, H. Z., and Sajjadi, S. M. (2019). Covalently Bonded Dithiocarbamate-Terminated Hyperbranched Polyamidoamine Polymer on Magnetic Graphene Oxide Nanosheets as an Efficient Sorbent for Preconcentration and Separation of Trace Levels of Some Heavy Metal Ions in Food Samples. Food Measure 14 (1), 293-302. doi:10.1007/s11694-01900291-5

Luan, L., Tang, B., Liu, Y., Wang, A., Zhang, B., Xu, W., et al. (2021). Selective Capture of $\mathrm{Hg}(\mathrm{II})$ and $\mathrm{Ag}(\mathrm{I})$ from Water by Sulfur-Functionalized Polyamidoamine Dendrimer/magnetic $\mathrm{Fe}_{3} \mathrm{O}_{4}$ Hybrid Materials. Sep. Purif. Tech. 257, 117902. doi:10.1016/j.seppur.2020.117902

Luan, L., Tang, B., Ma, S., Sun, L., Xu, W., Wang, A., et al. (2021). Removal of Aqueous $\mathrm{Zn}(\mathrm{II})$ and Ni(II) by Schiff Base Functionalized PAMAM Dendrimer/ silica Hybrid Materials. J. Mol. Liquids 330, 115634. doi:10.1016/j.molliq.2021. 115634

Luo, M. B., Xiong, Y. Y., Wu, H. Q., Feng, X. F., Li, J. Q., and Luo, F. (2017). The $\mathrm{MOF}^{+}$Technique: A Significant Synergic Effect Enables High Performance Chromate Removal. Angew. Chem. Int. Ed. 56 (51), 16376-16379. doi:10.1002/ anie.201709197 
Ma, F., Qu, R., Sun, C., Wang, C., Ji, C., Zhang, Y., et al. (2009). Adsorption Behaviors of $\mathrm{Hg}(\mathrm{II})$ on Chitosan Functionalized by Amino-Terminated Hyperbranched Polyamidoamine Polymers. J. Hazard. Mater. 172 (2-3), 792-801. doi:10.1016/j.jhazmat.2009.07.066

Ma, L., Islam, S. M., Xiao, C., Zhao, J., Liu, H., Yuan, M., et al. (2017). Rapid Simultaneous Removal of Toxic Anions $\left[\mathrm{HSeO}_{3}\right]^{-},\left[\mathrm{SeO}_{3}\right]^{2-}$, and $\left[\mathrm{SeO}_{4}\right]^{2-}$, and Metals $\mathrm{Hg}^{2+}, \mathrm{Cu}^{2+}$, and $\mathrm{Cd}^{2+}$ by $\mathrm{MoS}_{4}{ }^{2-}$ Intercalated Layered Double Hydroxide. J. Am. Chem. Soc. 139 (36), 12745-12757. doi:10.1021/jacs.7b07123

Ma, Y.-X., Xing, D., Shao, W.-J., Du, X.-Y., and La, P.-Q. (2017). Preparation of Polyamidoamine Dendrimers Functionalized Magnetic Graphene Oxide for the Adsorption of $\mathrm{Hg}(\mathrm{II})$ in Aqueous Solution. J. Colloid Interf. Sci. 505, 352-363. doi:10.1016/j.jcis.2017.05.104

Ma, Y. X., Shao, W. J., Jin, P. S., Kou, Y. L., and Li, X. (2018). Magnetic Graphene Oxide Grafted with Different Hydrophobic Chain Lengths Low-generation Polyamidoamine Dendrimers for Adsorption of $\mathrm{Pb}(\mathrm{II})$ and $\mathrm{Hg}(\mathrm{II})$ in Aqueous Solution. Polym. Compos. 40 (S2), E1685-E1696. doi:10.1002/pc.25122

Makaremi, M., De Silva, R. T., and Pasbakhsh, P. (2015). Electrospun Nanofibrous Membranes of Polyacrylonitrile/Halloysite with Superior Water Filtration Ability. J. Phys. Chem. C 119 (14), 7949-7958. doi:10.1021/acs.jpcc.5b00662

Maleki, A., Hayati, B., Najafi, F., Gharibi, F., and Joo, S. W. (2016). Heavy Metal Adsorption from Industrial Wastewater by $\mathrm{PAMAM} / \mathrm{TiO}_{2}$ Nanohybrid: Preparation, Characterization and Adsorption Studies. J. Mol. Liquids 224, 95-104. doi:10.1016/j.molliq.2016.09.060

Mariana, M., H.P.S., A. K., Mistar, E. M., Yahya, E. B., Alfatah, T., Danish, M., et al. (2021). Recent Advances in Activated Carbon Modification Techniques for Enhanced Heavy Metal Adsorption. J. Water Process Eng. 43, 102221. doi:10. 1016/j.jwpe.2021.102221

Moazzen, M., Mousavi Khaneghah, A., Shariatifar, N., Ahmadloo, M., Eş, I., Baghani, A. N., et al. (2019). Multi-walled Carbon Nanotubes Modified with Iron Oxide and Silver Nanoparticles (MWCNT- $\mathrm{Fe}_{3} \mathrm{O}_{4} / \mathrm{Ag}$ ) as a Novel Adsorbent for Determining PAEs in Carbonated Soft Drinks Using Magnetic SPE-GC/MS Method. Arabian J. Chem. 12 (4), 476-488. doi:10. 1016/j.arabjc.2018.03.003

Myers, V. S., Weir, M. G., Carino, E. V., Yancey, D. F., Pande, S., and Crooks, R. M. (2011). Dendrimer-encapsulated Nanoparticles: New Synthetic and Characterization Methods and Catalytic Applications. Chem. Sci. 2, 1632. doi:10.1039/c1sc00256b

Niu, Y., Qu, R., Chen, H., Mu, L., Liu, X., Wang, T., et al. (2014). Synthesis of Silica Gel Supported Salicylaldehyde Modified PAMAM Dendrimers for the Effective Removal of $\mathrm{Hg}(\mathrm{II})$ from Aqueous Solution. J. Hazard. Mater. 278, 267-278. doi:10.1016/j.jhazmat.2014.06.012

Niu, Y., Qu, R., Sun, C., Wang, C., Chen, H., Ji, C., et al. (2013). Adsorption of $\mathrm{Pb}$ (II) from Aqueous Solution by Silica-Gel Supported Hyperbranched Polyamidoamine Dendrimers. J. Hazard. Mater. 244-245, 276-286. doi:10. 1016/j.jhazmat.2012.11.042

Niu, Y., Yang, J., Qu, R., Gao, Y., Du, N., Chen, H., et al. (2016). Synthesis of SilicaGel-Supported Sulfur-Capped PAMAM Dendrimers for Efficient $\mathrm{Hg}(\mathrm{II})$ Adsorption: Experimental and DFT Study. Ind. Eng. Chem. Res. 55 (12), 3679-3688. doi:10.1021/acs.iecr.6b00172

Pawlaczyk, M., and Schroeder, G. (2019). Adsorption Studies of Cu(II) Ions on Dendrimer-Grafted Silica-Based Materials. J. Mol. Liquids 281, 176-185. doi:10. 1016/j.molliq.2019.02.043

Pawlaczyk, M., and Schroeder, G. (2020). Efficient Removal of Ni(II) and Co(II) Ions from Aqueous Solutions Using Silica-Based Hybrid Materials Functionalized with PAMAM Dendrimers. Solvent Extraction and Ion Exchange 38 (5), 496-521. doi:10.1080/07366299.2020.1766742

Pourjavadi, A., Abedin-Moghanaki, A., and Hosseini, S. H. (2016). Synthesis of Poly(amidoamine)-Graft-Poly(methyl Acrylate) Magnetic Nanocomposite for Removal of lead Contaminant from Aqueous media. Int. J. Environ. Sci. Technol. 13 (10), 2437-2448. doi:10.1007/s13762-016-1063-7

Priyadarshini, N., and Ilaiyaraja, P. (2019). Adsorption of U(VI) and Th(IV) from Simulated Nuclear Waste Using PAMAM and DGA Functionalized PAMAM dendron Grafted Styrene Divinylbenzene Chelating Resins. Chem. Pap. 73 (11), 2879-2884. doi:10.1007/s11696-019-00830-w

Pujari, S. P., Scheres, L., Marcelis, A. T. M., and Zuilhof, H. (2014). Covalent Surface Modification of Oxide Surfaces. Angew. Chem. Int. Ed. 53 (25), 6322-6356. doi:10.1002/anie.201306709
Qiao, W., Zhang, P., Sun, L., Ma, S., Xu, W., Xu, S., et al. (2020). Adsorption Performance and Mechanism of Schiff Base Functionalized Polyamidoamine Dendrimer/silica for Aqueous $\mathrm{Mn}(\mathrm{II})$ and $\mathrm{Co}(\mathrm{II})$. Chin. Chem. Lett. 31 (10), 2742-2746. doi:10.1016/j.cclet.2020.04.036

Qin, W., Qian, G., Tao, H., Wang, J., Sun, J., Cui, X., et al. (2019). Adsorption of $\mathrm{Hg}$ (II) Ions by PAMAM Dendrimers Modified Attapulgite Composites. Reactive Funct. Polym. 136, 75-85. doi:10.1016/j.reactfunctpolym.2019. 01.005

Qiu, Z., Niu, Y., Fu, T., Wang, K., Mu, Q., and Wang, F. (2019). Removal of Ni(II) from Fuel Ethanol by PAMAM Dendrimers/silica Hybrid Materials: Combined Experimental and Theoretical Study. Chem. Eng. Res. Des. 144, 174-184. doi:10. 1016/j.cherd.2019.02.002

Qu, R., Niu, Y., Liu, J., Sun, C., Zhang, Y., Chen, H., et al. (2008). Adsorption and Desorption Behaviors of Pd(II) on Silica-Gel Functionalized with Ester- and Amino-Terminated Dendrimer-like Polyamidoamine Polymers. Reactive Funct. Polym. 68 (8), 1272-1280. doi:10.1016/j.reactfunctpolym.2008.06.005

Qu, R., Sun, C., Ji, C., Wang, C., Chen, H., Niu, Y., et al. (2008). Preparation and Metal-Binding Behaviour of Chitosan Functionalized by Ester- and AminoTerminated Hyperbranched Polyamidoamine Polymers. Carbohydr. Res. 343 (2), 267-273. doi:10.1016/j.carres.2007.10.032

Radi, S., Toubi, Y., El-Massaoudi, M., Bacquet, M., Degoutin, S., and Mabkhot, Y. N. (2016). Efficient Extraction of Heavy Metals from Aqueous Solution by Novel Hybrid Material Based on Silica Particles Bearing New Schiff Base Receptor. J. Mol. Liquids 223, 112-118. doi:10.1016/j.molliq.2016.08.024

Ren, B., Wang, K., Zhang, B., Li, H., Niu, Y., Chen, H., et al. (2019). Adsorption Behavior of PAMAM Dendrimers Functionalized Silica for Cd(II) from Aqueous Solution: Experimental and Theoretical Calculation. J. Taiwan Inst. Chem. Eng. 101, 80-91. doi:10.1016/j.jtice.2019.04.037

Rether, A., and Schuster, M. (2003). Selective Separation and Recovery of Heavy Metal Ions Using Water-Soluble N-Benzoylthiourea Modified PAMAM Polymers. Reactive Funct. Polym. 57 (1), 13-21. doi:10.1016/j. reactfunctpolym.2003.06.002

Sayari, A., Hamoudi, S., and Yang, Y. (2015). Applications of Pore-Expanded Mesoporous Silica. 1. Removal of Heavy Metal Cations and Organic Pollutants from Wastewater. Chem. Mater. 17 (1), 212-216. doi:10.1021/cm048393e

Shahbazi, A., Younesi, H., and Badiei, A. (2013). Batch and Fixed-Bed Column Adsorption of $\mathrm{Cu}(\mathrm{II}), \mathrm{Pb}(\mathrm{II})$ and $\mathrm{Cd}(\mathrm{II})$ from Aqueous Solution onto Functionalised SBA-15 Mesoporous Silica. Can. J. Chem. Eng. 91 (4), 739-750. doi:10.1002/cjce.21691

Shih, Y.-J., Chien, S.-K., Jhang, S.-R., and Lin, Y.-C. (2019). Chemical Leaching, Precipitation and Solvent Extraction for Sequential Separation of Valuable Metals in Cathode Material of Spent Lithium Ion Batteries. J. Taiwan Inst. Chem. Eng. 100, 151-159. doi:10.1016/j.jtice.2019.04.017

Song, X., Niu, Y., Qiu, Z., Zhang, Z., Zhou, Y., Zhao, J., et al. (2017). Adsorption of $\mathrm{Hg}(\mathrm{II})$ and $\mathrm{Ag}(\mathrm{I})$ from Fuel Ethanol by Silica Gel Supported Sulfur-Containing PAMAM Dendrimers: Kinetics, Equilibrium and Thermodynamics. Fuel 206, 80-88. doi:10.1016/j.fuel.2017.05.086

Su, C.-J., Tang, Y.-H., Yu, F.-L., Wu, R.-R., Hsu, S. C. N., Kao, C.-L., et al. (2012). Extraction of Cupric Ions with Ionic Liquids Containing Polypyridine-type Small Molecules or Peripherally Pyridine-Modified Dendrimers. Chem. Asian J. 7 (10), 2438-2445. doi:10.1002/asia.201200447

Sun, C., Ma, F., Zhang, G., Qu, R., and Zhang, Y. (2011). Removal of Mercury Ions from Ethanol Solution Using Silica Gel Functionalized with Amino-Terminated Dendrimer-like Polyamidoamine Polymers: Kinetics and Equilibrium Studies. J. Chem. Eng. Data 56 (12), 4407-4415. doi:10.1021/je200235j

Sun, H., Zhang, X., He, Y., Zhang, D., Feng, X., Zhao, Y., et al. (2019). Preparation of PVDF-G-PAA-PAMAM Membrane for Efficient Removal of Copper Ions. Chem. Eng. Sci. 209, 115186. doi:10.1016/j.ces.2019.115186

Sun, S., Wang, L., and Wang, A. (2006). Adsorption Properties of Crosslinked Carboxymethyl-Chitosan Resin with $\mathrm{Pb}(\mathrm{II})$ as Template Ions. J. Hazard. Mater. 136 (3), 930-937. doi:10.1016/j.jhazmat.2006.01.033

Sun, Y., Li, D., Yang, H., and Guo, X. (2018). Fabrication of $\mathrm{Fe}_{3} \mathrm{O}_{4} @$ polydopamine@polyamidoamine Core-Shell Nanocomposites and Their Application for $\mathrm{Cu}(\mathrm{ii})$ Adsorption. New J. Chem. 42 (14), 12212-12221. doi:10.1039/c8nj01815d

Surgutskaia, N. S., Martino, A. D., Zednik, J., Ozaltin, K., Lovecká, L., Bergerová, E. D., et al. (2020). Efficient $\mathrm{Cu}^{2+}, \mathrm{Pb}^{2+}$ and $\mathrm{Ni}^{2+}$ Ion Removal from Wastewater 
Using Electrospun DTPA-Modified Chitosan/polyethylene Oxide Nanofibers. Sep. Purif. Technol. 247, 116014. doi:10.1016/j.seppur.2020.116914

Swali, V., Wells, N. J., Langley, G. J., and Bradley, M. (1997). Solid-Phase Dendrimer Synthesis and the Generation of Super-high-loading Resin Beads for Combinatorial Chemistry. J. Org. Chem. 62, 4902-4903. doi:10.1021/ jo9708654

Tabatabaiee Bafrooee, A. A., Ahmad Panahi, H., Moniri, E., Miralinaghi, M., and Hasani, A. H. (2020). Removal of $\mathrm{Hg}^{2+}$ by Carboxyl-Terminated Hyperbranched Poly(amidoamine) Dendrimers Grafted Superparamagnetic Nanoparticles as an Efficient Adsorbent. Environ. Sci. Pollut. Res. 27 (9), 9547-9567. doi:10.1007/s11356-019-07377-z

Tan, X.-f., Liu, Y.-g., Gu, Y.-l., Xu, Y., Zeng, G.-m., Hu, X.-j., et al. (2016). Biocharbased Nano-Composites for the Decontamination of Wastewater: A Review. Bioresour. Tech. 212, 318-333. doi:10.1016/j.biortech.2016.04.093

Tao, J., Xiong, J., Jiao, C., Zhang, D., Lin, H., and Chen, Y. (2017). Cellulose/ polymer/silica Composite Cotton Fiber Based on a HyperbranchMesostructure System as Versatile Adsorbent for Water Treatment. Carbohydr. Polym. 166, 271-280. doi:10.1016/j.carbpol.2017.02.109

Tofighy, M. A., and Mohammadi, T. (2011). Adsorption of Divalent Heavy Metal Ions from Water Using Carbon Nanotube Sheets. J. Hazard. Mater. 185 (1), 140-147. doi:10.1016/j.jhazmat.2010.09.008

Tomalia, D. A. (2005). Birth of a New Macromolecular Architecture: Dendrimers as Quantized Building Blocks for Nanoscale Synthetic Polymer Chemistry. Prog. Polym. Sci. 30 (3-4), 294-324. doi:10.1016/j.progpolymsci.2005.01.007

Tomalia, D. A., Naylor, A. M., and Goddard, W. A. (2010). Starburst Dendrimers: Molecular-Level Control of Size, Shape, Surface Chemistry, Topology, and Flexibility from Atoms to Macroscopic Matter. Angew. Chem. Int. Edit. 29 (2), 138-175. doi:10.1002/anie.199001381

Valdés, O., Vergara, C., Nachtigall, F. M., Lopez-Cabaña, Z., Tapia, J., and Santos, L. S. (2016). Pamam Built-On-Silicon Wafer Thin-Layer Extraction Devices for Selective Metal Contamination Detection. Tetrahedron Lett. 57 (23), 2468-2473. doi:10.1016/j.tetlet.2016.04.063

Vasiliev, A. N., Golovko, L. V., Trachevsky, V. V., Hall, G. S., and Khinast, J. G. (2009). Adsorption of Heavy Metal Cations by Organic Ligands Grafted on Porous Materials. Micropor Mesopor Mat 118 (1-3), 251-257. doi:10.1016/j. micromeso.2008.08.026

Venkateswarlu, S., Himagirish Kumar, S., and Jyothi, N. V. V. (2015). Rapid Removal of Ni(II) from Aqueous Solution Using 3-Mercaptopropionic Acid Functionalized Bio Magnetite Nanoparticles. Water Resour. Industry 12, 1-7. doi:10.1016/j.wri.2015.09.001

Wang, F., Sun, Y., Guo, X., Li, D., and Yang, H. (2020). Preparation and Graft Modification of Hierarchically Porous Ferriferrous Oxide for Heavy Metal Ions Adsorption. J. Sol-gel Sci. Technol. 96 (2), 360-369. doi:10.1007/s10971-02005350-8

Wang, N., Zhu, L., Wang, D., Wang, M., Lin, Z., and Tang, H. (2010). Sono-assisted Preparation of Highly-Efficient Peroxidase-like $\mathrm{Fe}_{3} \mathrm{O}_{4}$ Magnetic Nanoparticles for Catalytic Removal of Organic Pollutants with $\mathrm{H}_{2} \mathrm{O}_{2}$. Ultrason. Sonochem. 17 (3), 526-533. doi:10.1016/j.ultsonch.2009.11.001

Wang, Y., and Lu, Q. (2019). Dendrimer Functionalized Nanocrystalline Cellulose for $\mathrm{Cu}(\mathrm{II})$ Removal. Cellulose 27 (4), 2173-2187. doi:10.1007/s10570-01902919-7

Wei, Y., Han, B., Hu, X., Lin, Y., Wang, X., and Deng, X. (2012). Synthesis of $\mathrm{Fe}_{3} \mathrm{O}_{4}$ Nanoparticles and Their Magnetic Properties. Proced. Eng. 27, 632-637. doi:10. 1016/j.proeng.2011.12.498

Weidman, J. L., Mulvenna, R. A., Boudouris, B. W., and Phillip, W. A. (2017). Nanoporous Block Polymer Thin Films Functionalized with Bio-Inspired Ligands for the Efficient Capture of Heavy Metal Ions from Water. ACS Appl. Mater. Inter. 9 (22), 19152-19160. doi:10.1021/acsami.7b04603

Wu, M., Ma, T., Su, Y., Wu, H., You, X., Jiang, Z., et al. (2017). Fabrication of Composite Nanofiltration Membrane by Incorporating Attapulgite Nanorods during Interfacial Polymerization for High Water Flux and Antifouling Property. J. Membr. Sci. 544, 79-87. doi:10.1016/j.memsci.2017.09.016

Wu, X., Luo, L., Chen, Z., and Liang, K. (2006). Syntheses, Characterization, and Adsorption Properties for Metal Ions of Silica-Gel Functionalized by Ester- and Amino-Terminated Dendrimer-like Polyamidoamine Polymer. Micropor Mesopor Mat 97 (1-3), 58-65. doi:10.1016/j.apsusc.2015.12.084

$\mathrm{Wu}, \mathrm{X}$., Luo, L., Chen, Z., and Liang, K. (2016). Syntheses, Characterization and Adsorption Properties for $\mathrm{Pb} 2+$ of Silica-Gel Functionalized by Dendrimer-like
Polyamidoamine and 5-sulfosalicylic Acid. Appl. Surf. Sci. 364, 86-95. doi:10. 1016/j.apsusc.2015.12.084

Xiao, W., Yan, B., Zeng, H., and Liu, Q. (2016). Dendrimer Functionalized Graphene Oxide for Selenium Removal. Carbon 105, 655-664. doi:10.1016/j. carbon.2016.04.057

Xie, Y., Huang, Q., Liu, M., Wang, K., Wan, Q., Deng, F., et al. (2015). Mussel Inspired Functionalization of Carbon Nanotubes for Heavy Metal Ion Removal. RSC Adv. 5 (84), 68430-68438. doi:10.1039/c5ra08908e

Yin, R., Niu, Y., Zhang, B., Chen, H., Yang, Z., Yang, L., et al. (2019). Removal of $\mathrm{Cr}(\mathrm{III})$ from Aqueous Solution by Silica-Gel/PAMAM Dendrimer Hybrid Materials. Environ. Sci. Pollut. Res. 26 (18), 18098-18112. doi:10.1007/ s11356-019-05220-Z

Yin, Z., Zhu, L., Mo, F., Li, S., Hu, D., Chu, R., et al. (2021). Preparation of Biochar Grafted with Amino-Riched Dendrimer by Carbonization, Magnetization and Functional Modification for Enhanced Copper Removal. J. Taiwan Inst. Chem. Eng. 121, 349-359. doi:10.1016/j.jtice.2021.04.014

Yu, D., Wang, Y., Wu, M., Zhang, L., Wang, L., and Ni, H. (2019). Surface Functionalization of Cellulose with Hyperbranched Polyamide for Efficient Adsorption of Organic Dyes and Heavy Metals. J. Clean. Prod. 232, 774-783. doi:10.1016/j.jclepro.2019.06.024

Yuan, D., Chen, L., Xiong, X., Zhang, Q., Liao, S., Yuan, L., et al. (2016). Synthesis of PAMAM dendron Functionalized Superparamagnetic Polymer Microspheres for Highly Efficient Sorption of Uranium(VI). J. Radioanal. Nucl. Chem. 309 (3), 1227-1240. doi:10.1007/s10967-016-4735-3

Yuan, Y., An, Z., Zhang, R., Wei, X., and Lai, B. (2021). Efficiencies and Mechanisms of Heavy Metals Adsorption on Waste Leather-Derived HighNitrogen Activated Carbon. J. Clean. Prod. 293, 126215. doi:10.1016/j.jclepro. 2021.126215

Yuan, Y., Zhang, G., Li, Y., Zhang, G., Zhang, F., and Fan, X. (2013). Poly(amidoamine) Modified Graphene Oxide as an Efficient Adsorbent for Heavy Metal Ions. Polym. Chem. 4 (6), 2164-2167. doi:10.1039/ c3py21128b

Zarghami, Z., Akbari, A., Latifi, A. M., and Amani, M. A. (2016). Design of a New Integrated Chitosan-PAMAM Dendrimer Biosorbent for Heavy Metals Removing and Study of its Adsorption Kinetics and Thermodynamics. Bioresour. Tech. 205, 230-238. doi:10.1016/j.biortech.2016.01.052

Zhang, C., Wang, H., Gao, C., Chen, E., Wang, H., and Hong, L. (2021). Equilibrium and Kinetics Studies of $\mathrm{Cu}(\mathrm{II})$ Ions Adsorption on Polyamidoamine Dendrimer Starch. Res. Chem. Intermediate 38 (9), 2411-2425.

Zhang, C., Zhang, F., Li, L., and Zhang, K. (2016). Adsorption Rare Earth Metal Ions from Aqueous Solution by Polyamidoamine Dendrimer Functionalized Soy Hull. Waste Biomass Valor. 7 (5), 1211-1219. doi:10.1007/s12649-016-9514-4

Zhang, F., Wang, B., He, S., and Man, R. (2014). Preparation of Graphene-Oxide/ Polyamidoamine Dendrimers and Their Adsorption Properties toward Some Heavy Metal Ions. J. Chem. Eng. Data 59 (5), 1719-1726. doi:10.1021/ je500219e

Zhang, H., Wang, T., Sui, Z., Zhang, Y., Sun, B., and Pan, W.-P. (2019). Enhanced Mercury Removal by Transplanting Sulfur-Containing Functional Groups to Biochar through Plasma. Fuel 253, 703-712. doi:10.1016/j.fuel.2019.05.068

Zhang, J., Zhai, S., Li, S., Xiao, Z., Song, Y., An, Q., et al. (2013). Pb(II) Removal of $\mathrm{Fe}_{3} \mathrm{O}_{4} @ \mathrm{SiO}_{2}-\mathrm{NH}_{2}$ Core-Shell Nanomaterials Prepared via a Controllable SolGel Process. Chem. Eng. J. 215-216, 461-471. doi:10.1016/j.cej.2012.11.043

Zhang, N., Qiu, H., Si, Y., Wang, W., and Gao, J. (2011). Fabrication of Highly Porous Biodegradable Monoliths Strengthened by Graphene Oxide and Their Adsorption of Metal Ions. Carbon 49 (3), 827-837. doi:10.1016/j.carbon.2010. 10.024

Zhang, P., Niu, Y., Qiao, W., Xue, Z., Bai, L., and Chen, H. (2018). Experimental and DFT Investigation on the Adsorption Mechanism of Silica Gel Supported Sulfur-Capped PAMAM Dendrimers for Ag(I). J. Mol. Liquids 263, 390-398. doi:10.1016/j.molliq.2018.05.023

Zhang, X.-M., Sarma, D., Wu, Y.-Q., Wang, L., Ning, Z.-X., Zhang, F.-Q., et al. (2016). Open-Framework Oxysulfide Based on the Supertetrahedral $\left[\mathrm{In}_{4} \mathrm{Sn}_{16} \mathrm{O}_{10} \mathrm{~S}_{34}\right]^{12-}$ Cluster and Efficient Sequestration of Heavy Metals. J. Am. Chem. Soc. 138 (17), 5543-5546. doi:10.1021/jacs.6b02959

Zhang, X., Qin, Y., Zhang, G., Zhao, Y., Lv, C., Liu, X., et al. (2019). Preparation of PVDF/Hyperbranched-Nano-Palygorskite Composite Membrane for Efficient Removal of Heavy Metal Ions. Polymers 11 (1), 156. doi:10.3390/ polym 11010156 
Zhang, Y. J., Chen, J. R., and Yan, X. Y. (2008). Equilibrium and Kinetics Studies on Adsorption of $\mathrm{Zn}$ (II) from Aqueous Solutions onto a Graft Copolymer of Cross-Linked Starch/acrylonitrile (CLSAGCP). Colloid Surf. A 316 (1-3), 190-193. doi:10.1016/j.colsurfa.2007.09.003

Zhao, G., Jiang, L., He, Y., Li, J., Dong, H., Wang, X., et al. (2011). Sulfonated Graphene for Persistent Aromatic Pollutant Management. Adv. Mater. 23 (34), 3959-3963. doi:10.1002/adma.201101007

Zhao, J., Zhang, X., He, X., Xiao, M., Zhang, W., and Lu, C. (2015). A Super Biosorbent from Dendrimer Poly(amidoamine)-Grafted Cellulose Nanofibril Aerogels for Effective Removal of Cr(vi). J. Mater. Chem. A. 3 (28), 14703-14711. doi:10.1039/c5ta03089g

Zhao, N., Zhao, C., Lv, Y., Zhang, W., Du, Y., Hao, Z., et al. (2017). Adsorption and Coadsorption Mechanisms of $\mathrm{Cr}(\mathrm{VI})$ and Organic Contaminants on $\mathrm{H}_{3} \mathrm{PO}_{4}$ Treated Biochar. Chemosphere 186, 422-429. doi:10.1016/j.chemosphere.2017. 08.016

Zhao, X., Wang, Y., Li, D. S., Bu, X., and Feng, P. (2018). Metal-Organic Frameworks for Separation. Adv. Mater. 30 (37), e1705189. doi:10.1002/ adma.201705189

Zhao, Y., Abdullayev, E., Vasiliev, A., and Lvov, Y. (2013). Halloysite Nanotubule clay for Efficient Water Purification. J. Colloid Interf. Sci. 406, 121-129. doi:10. 1016/j.jcis.2013.05.072

Zhou, L., Duan, Y., and Xu, X. (2019). Facile Preparation of Amine-Rich Polyamidoamine (PAMAM) Gel for Highly Efficient Removal of $\mathrm{Cr}(\mathrm{VI})$ Ions. Colloids Surf. A: Physicochemical Eng. Aspects 579, 123685. doi:10. 1016/j.colsurfa.2019.123685

Zhou, S., Xue, A., Zhang, Y., Li, M., Li, K., Zhao, Y., et al. (2015). Novel Polyamidoamine Dendrimer-Functionalized Palygorskite Adsorbents with High Adsorption Capacity for $\mathrm{Pb}^{2+}$ and Reactive Dyes. Appl. Clay Sci. 107, 220-229. doi:10.1016/j.clay.2015.01.032
Zhou, Y., Fuentes-Hernandez, C., Khan, T. M., Liu, J.-C., Hsu, J., Shim, J. W., et al. (2013). Recyclable Organic Solar Cells on Cellulose Nanocrystal Substrates. Sci. Rep. 3, 1536. doi:10.1038/srep01536

Zhou, Y., Luan, L., Tang, B., Niu, Y., Qu, R., Liu, Y., et al. (2020). Fabrication of Schiff Base Decorated PAMAM Dendrimer/magnetic $\mathrm{Fe}_{3} \mathrm{O}_{4}$ for Selective Removal of Aqueous Hg(II). Chem. Eng. J. 398, 125651. doi:10.1016/j.cej. 2020.125651

Zhu, Y., Niu, Y., Li, H., Ren, B., Qu, R., Chen, H., et al. (2018). Removal of Cd(II) and Fe(III) from DMSO by Silica Gel Supported PAMAM Dendrimers: Equilibrium, Thermodynamics, Kinetics and Mechanism. Ecotoxicology Environ. Saf. 162, 253-260. doi:10.1016/j.ecoenv.2018.06.094

Conflict of Interest: The authors declare that the research was conducted in the absence of any commercial or financial relationships that could be construed as a potential conflict of interest.

Publisher's Note: All claims expressed in this article are solely those of the authors and do not necessarily represent those of their affiliated organizations, or those of the publisher, the editors and the reviewers. Any product that may be evaluated in this article, or claim that may be made by its manufacturer, is not guaranteed or endorsed by the publisher.

Copyright (c) 2022 Wang, Zhu, Xi and Zhang. This is an open-access article distributed under the terms of the Creative Commons Attribution License (CC $B Y)$. The use, distribution or reproduction in other forums is permitted, provided the original author(s) and the copyright owner(s) are credited and that the original publication in this journal is cited, in accordance with accepted academic practice. No use, distribution or reproduction is permitted which does not comply with these terms. 